\title{
Checklist of the superfamily Scarabaeoidea (Insecta, Coleoptera) in an urban area of the Caribbean Colombia
}

\author{
Carlos Taboada-Verona ${ }^{1}$, Carlos Sermeño-Correa ${ }^{2}$, Oscar Sierra-Serrano ${ }^{1}$, Jorge Ari Noriega ${ }^{3}$ \\ 1 Grupo Evolución y Sistemática Tropical, Universidad de Sucre, Colombia. 2 Grupo Investigaciones Biomédicas, Universidad de Sucre, Sincelejo, \\ Colombia. 3 Laboratorio de Zoología y Ecología Acuática (LAZOEA), Universidad de Los Andes, Bogotá, Colombia. \\ Corresponding author. Jorge Ari Noriega, jnorieg@hotmail.com
}

\begin{abstract}
We report an inventory of the superfamily Scarabaeoidea present at the campus of the University of Sucre, Sincelejo, Colombia. Specimens were captured between the months of May and June 2016. A total of 510 specimens were collected belonging to 3 families, 8 subfamilies, 27 genera, and 34 species. The subfamilies presenting the greatest diversity were Scarabaeinae and Dynastinae. For the first time the following 8 species were recorded for Sucre Department: Anomala valida Burmeister, 1844, Liogenys quadridens (Fabricius, 1798), Megasoma elephas (Fabricius, 1775), Omorgus suberosus (Fabricius, 1775), Phileurus didymus (Linnaeus, 1758), Phileurus valgus (Olivier, 1789), Phyllophaga menetriesi (Blanchard, 1850), and Xenopelidnota anomala (Burmeister, 1844). We highlight the importance of green zones within urban areas as possible faunistic refugia for different taxonomic groups, especially for the beetles of the superfamily Scarabaeoidea.
\end{abstract}

\section{Key words}

Faunistics, lamellicorn, Neotropical region, new records, species distribution, taxonomy.

Academic editor: Juan Pablo Botero | Received 12 February 2019 | Accepted 11 April 2019 | Published 26 July 2019

Citation: Taboada-Verona C, Sermeño-Correa C, Sierra-Serrano O, Noriega JA (2019) Checklist of the superfamily Scarabaeoidea (Insecta, Coleoptera) in an urban area of the Caribbean Colombia. Check List 15 (4): 579-594. https://doi.org/10.15560/15.4.579

\section{Introduction}

The environmental impact caused by human activities, such as urbanization, negatively affects biodiversity (McKinney 2008) due to modification of natural systems brought about by the transformation or loss of their original structural composition (Vitousek et al. 1997). Biodiversity loss in urban settlements is primarily caused by the reduction, isolation, and low connectivity of green areas, as well as by the scarcity of nourishment (Fattorini 2011) and other factors such as chemical and noise pollution (Lovett et al. 2009, Proppe et al. 2013). In urban areas, the least perturbed habitats and soils are found primarily in peripheral zones (McDonnell and Pickett 1990); however, there are other sectors within cities such as parks, freshwater sources, or abandoned terrains that can turn into habitats or refugia for the surviving populations.

Insects are one of the most abundant animal groups in urban areas (McIntyre 2000), but little is known about their species richness and response to the impacts of urbanization. Insects play diverse and vital functional processes in ecosystems (Fisher 1998). Beetles of the superfamily Scarabaeoidea consists of approximately 35000 species (Schoolmeesters 2019) and constitutes one of the most important groups within the 

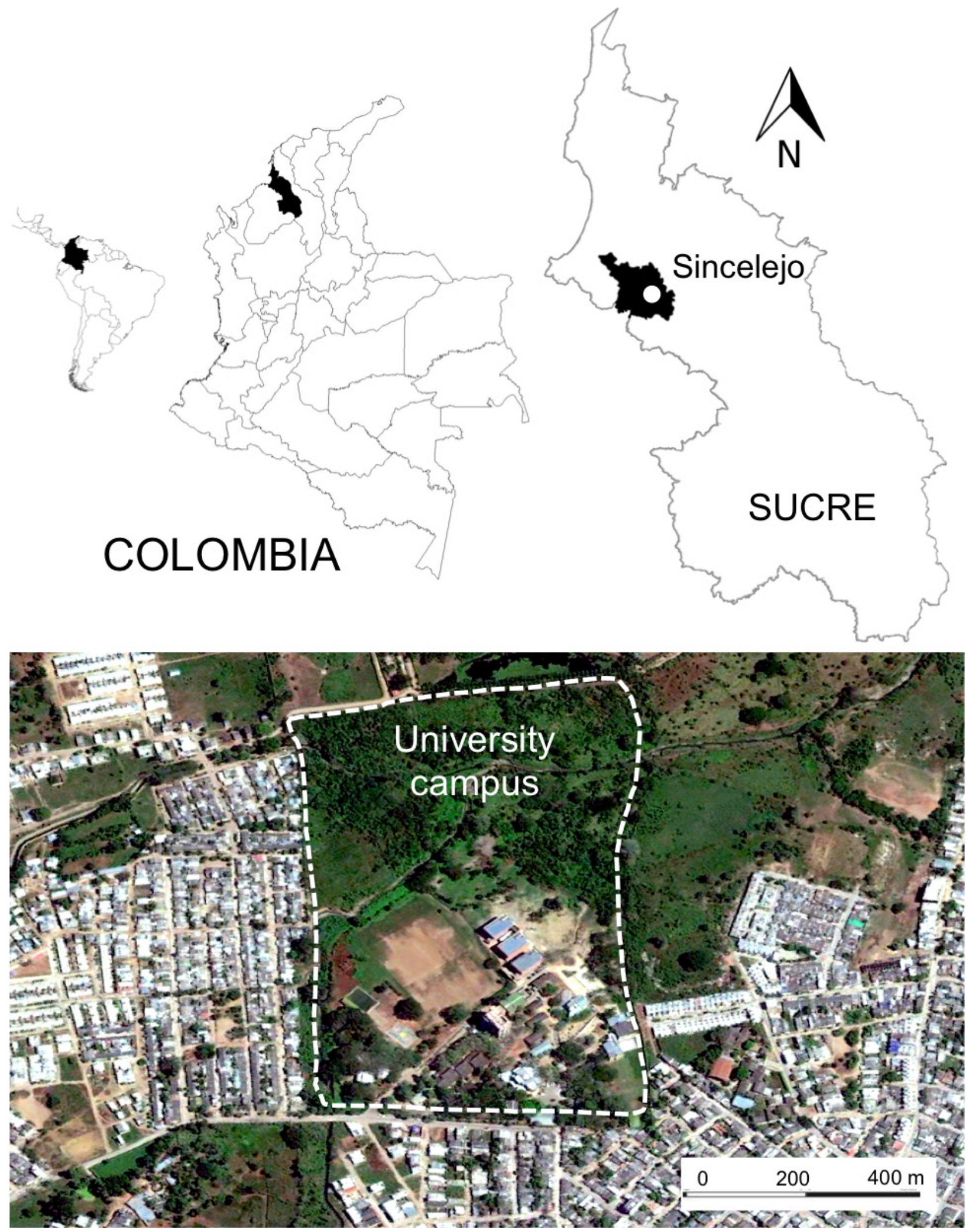

Figure 1. Location of the study area at the University of Sucre campus, Sincelejo, Sucre, Colombia. Photo taken with a VOOCO X-Star Drone with a $4 \mathrm{~K}$ camera.

order Coleoptera (Grebennikov and Scholtz 2004). Due to their fundamental position within the trophic chain, they are important in contributing to pollination, decomposing organic matter, dispersing seeds, and controlling parasites (Grove 2002, Nichols et al. 2007). They have been used in basic studies and as ecological indicators to evaluate the conservation and equilibrium status of ecosystems due to their biological relationships, abundance, broad geographical distribution, and well-known taxonomy (Delgado and Márquez 2006, Otavo et al. 2013).

In Colombia, Scarabaeoidea has been insufficiently studied (Amat-García and Trujillo 2004, Neita-Moreno 
2011, Otavo et al. 2013). The majority of effort has been in individual families or subfamilies or specific taxonomical surveys and ecological studies in agricultural areas and native forests (Pardo-Locarno et al. 2005, Navarro et al. 2011, García-Atencia and Martínez-Hernández 2015). Hence, we record the diversity of scarab beetles (Coleoptera, Scarabaeoidea) occurring at the University of Sucre campus. Our new data serves to contribute to the knowledge of scarab beetles in an urban area of Colombia.

\section{Methods}

Study site. The Universidad de Sucre $\left(09^{\circ} 18^{\prime} 52^{\prime \prime} \mathrm{N}\right.$, $\left.075^{\circ} 23^{\prime} 18^{\prime \prime} \mathrm{W}\right)$ is located in the city of Sincelejo, Sucre Department, the northern Colombia, at an altitude of 160 $\mathrm{m}$ a.s.l. (Fig. 1). The yearly average temperature is 27 ${ }^{\circ} \mathrm{C}$ and the relative humidity is $77 \%$ with a bimodal precipitation regime that ranges from 1000 to $1200 \mathrm{~mm}$ of rainfall (Aguilera 2005). The campus is 23 ha and has a Tropical Dry Forest (TDF) climate following the climate classification by Holdridge (1979). The vegetation is composed primarily of members of the families Arecaceae, Bignoniaceae, Euphorbiaceae, Fabaceae, Malvaceae, Moraceae, and Lamiaceae. The campus landscape consists in a mosaic of buildings, ornamental gardens, monocultures, and secondary vegetation.

Data collection. We performed our surveys over 6 weeks between the months of May and June 2016. Specimens were collected on campus installing pitfall traps baited with human excrement that were exposed for $48 \mathrm{~h}$, and white light traps that were exposed for $4 \mathrm{~h}$ (18:0021:00). In addition, we made random walks, examining decomposing wood, with a sampling effort of $2 \mathrm{~h}$ a day (19-21h). Trophic functional groups were delimited using the information of bait preferences from each trap and with complementary bibliographical information. All individuals were preserved in 70\% alcohol, labelled, and transported to the Conservation Laboratory of the University of Sucre. We used published taxonomic keys (Endrödi 1985, Scholtz 1990, Medina and Lopera 2000, Kohlmann and Solís 2001, Solís and Kohlmann 2002, 2004, Smith and Skelley 2007, Ramírez-Ponce and Morón 2009, Camero 2010, Jiménez-Ferbans and AmatGarcía 2010, Sanabria-García et al. 2012, Vallejo and Wolff 2013, Sarmiento-Garcés and Amat-García 2014, López-García et al. 2015, Filippini et al. 2016) to identify the specimens to the species level. All individuals were deposited in the Zoological Museum of the University of Sucre (MZUSU) in Sincelejo, Sucre, Colombia. In addition to newly collected specimens, we revised priorcollected specimens that were deposited in the MZUSU collection.

\section{Results}

We found 510 specimens belonging to 8 subfamilies, 27 genera, and 34 species. The family with the greatest

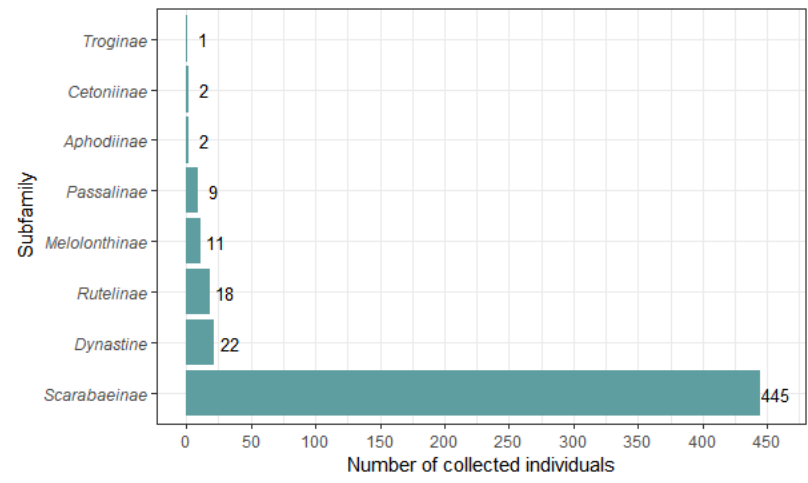

Figure 2. Number of individuals in each subfamily collected at the University of Sucre campus, Sincelejo, Sucre, Colombia.

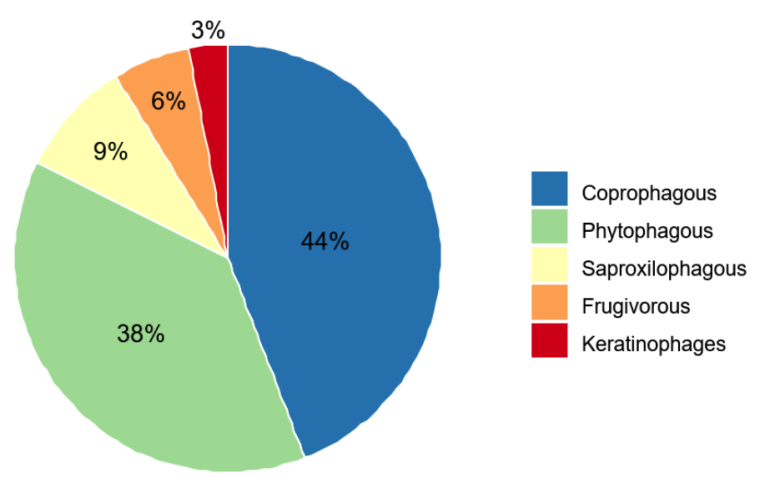

Figure 3. Composition of beetle functional trophic groups captured at the University of Sucre campus, Sincelejo, Sucre, Colombia.

species richness was the Scarabaeidae, with 30 species were recorded and belonging to 6 subfamilies: Scarabaeinae (41\%), Dynastinae (20\%), Rutelinae (12\%), Cetoniinae (6\%), Melolonthinae $(6 \%)$, and Aphodiinae (3\%). The most abundant subfamilies in terms of number of individuals were Scarabaeinae, Dynastinae, and Rutelinae (Fig. 2). Only 3 species represented Passalidae $(9 \%)$, belonging to a single tribe. The family Trogidae was represented by Omorgus suberosus (Fabricius, 1775 ) and constituted $3 \%$ of the total richness collected. The composition of trophic functional groups on campus was dominated by coprophagous and phytophagous beetles, and, to a lesser extent, keratinophages (Fig. 3).

Family Passalidae

Subfamily Passalinae

\section{Passalus interruptus (Linnaeus, 1758)}

Figure 4A

Geograpical distribution. Panama to Argentina and Trinidad and Tobago (Reyes-Castillo 1973, JiménezFerbans et al. 2015). In Colombia: Amazonas, Caquetá, Casanare, Chocó, Cordoba, Cundinamarca, Huila, Magdalena, Meta, Sucre, and Valle del Cauca (Reyes-Castillo and Amat-García 2003, Amat-García et al. 2004, Amat-García and Reyes-Castillo 2007, Jiménez-Ferbans and Amat-García 2009, Neita-Moreno 2011, SalazarNiño and Amat-García 2015).

Material examined. Colombia, Sucre, Sincelejo, Uni- 
versity of Sucre campus $\left(09^{\circ} 18^{\prime} 52^{\prime \prime} \mathrm{N}, 075^{\circ} 23^{\prime} 18^{\prime \prime} \mathrm{W}\right)$, 2016/03/19, MZUSU E02675 (1ㅇ).

Identification. This species can be distinguished from other Passalus species by its large size (48.84-50.70 mm), distally free central carina, rounded secondary tubercle, which is closer to the outer tubercle, elongate mesosternal scar marked with some setae in the anterior part of the mesosternum; last abdominal sternite incomplete.

\section{Passalus interstitialis Eschscholtz, 1829}

Figure 4B

Geograpical distribution. Mexico to Argentina, Cuba, Grenada, Jamaica, and Trinidad and Tobago (Arrow 1907, Hincks and Dibb 1935, Reyes-Castillo 1973, Ivie and Gillogly 1998, Peck et al. 2002, Jiménez-Ferbans et al. 2015). In Colombia: Amazonas, Antioquia, Bolívar, Caldas, Caquetá, Cauca, Cesar, Chocó, Córdoba, Cundinamarca, Guajira, Magdalena, Meta, Nariño, Quindío, Sucre, Tolima, Valle del Cauca, and Vichada (ReyesCastillo and Amat-García 2003, Amat-García et al. 2004, Amat-García and Reyes-Castillo 2007, Jiménez-Ferbans and Amat-García 2009, Neita-Moreno 2011, SalazarNiño and Amat-García 2015).

Material examined. Colombia, Sucre, Sincelejo, University of Sucre campus $\left(09^{\circ} 18^{\prime} 52^{\prime \prime} \mathrm{N}, 075^{\circ} 23^{\prime} 18^{\prime \prime} \mathrm{W}\right)$, 2016/05/07, MZUSU E02667 (1ㅇ).

Identification. This species can be distinguished from other Passalus species by its medium size (26.35-29.44 $\mathrm{mm}$ ), dorsoventrally flat body; sharp secondary tubercle and closer to the outer tubercle, and distally blunt and reduced central carina.

\section{Passalus punctiger Lepeletier \& Serville, 1825 Figure 4C}

Geograpical distribution. USA to Argentina, Grenada, Jamaica, Saint Vincent and the Grenadines, and Trinidad and Tobago (Reyes-Castillo 1973, Chalumeau 1978, Schhuster 1978, Peck et al. 2002, Peck 2010, JiménezFerbans et al. 2015). In Colombia: Amazonas, Antioquia, Atlántico, Bolívar, Boyacá, Casanare, Cauca, Cesar, Chocó, Córdoba, Cundinamarca, Guajira, Huila, Magdalena, Meta, Nariño, Quindío, Sucre, Tolima, Valle del Cauca, and Vichada (Reyes-Castillo and Amat-García 2003, Amat-García et al. 2004, Amat-García and ReyesCastillo 2007, Jiménez-Ferbans and Amat-García 2009, Neita-Moreno 2011, Salazar-Niño and Amat-García 2015).

Material examined. Colombia, Sucre, Sincelejo, University of Sucre campus $\left(09^{\circ} 18^{\prime} 52^{\prime \prime} \mathrm{N}, 075^{\circ} 23^{\prime} 18^{\prime \prime} \mathrm{W}\right)$, 2016/03/19, MZUSU E02668-E02671 (4ㅇ), MZUSU E02672-E02674 (3ठ).

Identification. This species can be distinguished from other Passalus species by its large size (29.85-42.50 $\mathrm{mm})$, dorsoventrally flat body, internal tubercle located on the outer tubercle, distally free central carina, elongated, glabrous mesosternal scar, and last abdominal sternite complete.
Family Scarabaeidae

Subfamily Cetoniinae

\section{Gymnetis stellata (Latreille, 1833)}

Figure 4D

Geographic distribution. Colombia, Panama, Mexico, Nicaragua, Peru, and Venezuela (Juárez and González 2017, Maes and Orozco 2017, Vásquez and HernándezCruz 2018). In Colombia: Antioquia, Bolívar, Chocó, Cundinamarca, Magdalena, Meta, Risaralda, Santander, Sucre, Tolima, and Valle del Cauca (Suárez and AmatGarcía 2007).

Material examined. Colombia, Sucre, Sincelejo, University of Sucre campus $\left(09^{\circ} 18^{\prime} 52^{\prime \prime} \mathrm{N}, 075^{\circ} 23^{\prime} 18^{\prime \prime} \mathrm{W}\right)$, 2017/09/28, MZUSU E02542 (1ठึ).

Identification. This species can be distinguished from other Gymnetis species by its velvety appearance and black coloration with yellow-orange rays; ventrally, his species is iridescent purple with yellowish gray patches.

\section{Hoplopyga liturata (Olivier, 1789)}

Figure 4E

Geographic distribution. Argentina, Belize, Brazil, Costa Rica, Guatemala, Mexico, Nicaragua, Panama, and Venezuela (Maes and Orozco 2017). In Colombia: Antioquia, Atlántico, Boyacá, Caldas, Casanare, Cauca, Chocó, Córdoba, Cundinamarca, Guaviare, Meta, Norte de Santander, Quindío, Santander, Sucre, and Valle del Cauca (Neita et al. 2006, Suárez and Amat-García 2007, García-Atencia et al. 2015, López-García et al. 2015).

Material examined. Colombia, Sucre, Sincelejo, University of Sucre campus $\left(09^{\circ} 18^{\prime} 52^{\prime \prime} \mathrm{N}, 075^{\circ} 23^{\prime} 18^{\prime \prime} \mathrm{W}\right)$, 2016/05/07, MZUSU E02543 (1 $\overbrace{}^{\lambda})$.

Identification. This species can be distinguished from other Hoplopyga species by its head which presents a very quadrangular clypeus, its matte body, and the elytra with punctures distributed in rows in the anterior and middle areas but more irregularly grouped in the posterior area.

\section{Subfamily Dynastinae}

\section{Dyscinetus dubius (Olivier, 1789)}

Figure 4F

Geographic distribution. Mexico to Argentina (Ratcliffe 1986). In Colombia: Antioquia, Atlántico, Boyacá, Casanare, Caquetá, Cauca, Cesar, Chocó, Córdoba, Cundinamarca, Huila, Meta, Risaralda, Santander, Sucre, Tolima, and Valle del Cauca (Restrepo-Giraldo et al. 2003, Pardo-Locarno et al. 2005, Neita-Moreno and Yepes 2011a, Neita-Moreno and Yepes 2011b, PardoLocarno et al. 2012, García-Atencia et al. 2015).

Material examined. Colombia, Sucre, Sincelejo, University of Sucre campus $\left(09^{\circ} 18^{\prime} 52^{\prime \prime} \mathrm{N}, 075^{\circ} 23^{\prime} 18^{\prime \prime} \mathrm{W}\right)$, 2016/05/11, MZUSU E02547 (1ð). 

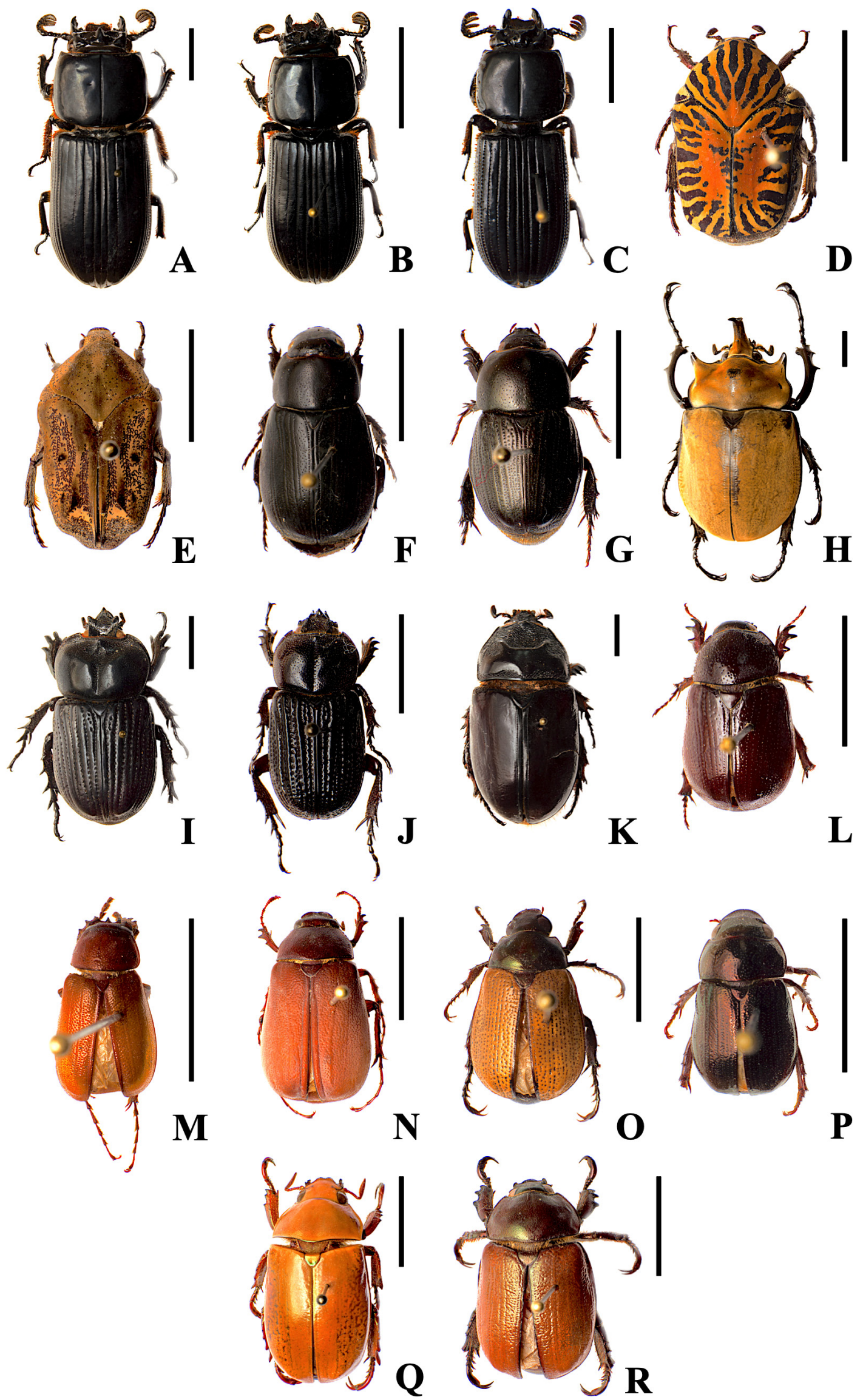

Figure 4. Beetles of superfamily Scarabaeoidea present at the University of Sucre campus. A. Passalus interruptus. B. Passalus interstitialis. C. Passalus punctiger. D. Gymnetis stellata. E. Hoplopyga liturata. F. Dyscinetus dubius. G. Euetheola humilis. H. Megasoma elephas. I. Phileurus didymus. J. Phileurus valgus. K. Strategus aloeus. L. Tomarus fossor. M. Liogenys quadridens. N. Phyllophaga menetriesi. O. Anomala valida. P. Leucothyreus cf. femoratus. Q. Pelidnota polita. R. Xenopelidnota anomala. Scale bars $=1 \mathrm{~cm}$. 
Identification. This species can be distinguished from other Dyscinetus species by its dark reddish chestnut body with green overtones evident, the elytra with very fine and uniform punctures, the protibia with pointed teeth, and the rough pygidium.

\section{Euetheola humilis (Burmeister, 1847)}

Figure 4G

Geograpical distribution. Southern USA to Argentina (Endrödi 1969, Ratcliffe and Cave 2006, Ratcliffe et al. 2013). In Colombia: Antioquia, Arauca, Atlántico, Bolívar, Casanare, Córdoba, Cundinamarca, Magdalena, Meta, Sucre, Tolima, and Valle del Cauca (RestrepoGiraldo et al. 2003, Lopez-Garcia et al. 2015).

Material examined. Colombia, Sucre, Sincelejo, University of Sucre campus $\left(09^{\circ} 18^{\prime} 52^{\prime \prime} \mathrm{N}, 075^{\circ} 23^{\prime} 18^{\prime \prime} \mathrm{W}\right)$, 2016/05/19, MZUSU E02509-E02512 (4).

Identification. Euetheola humilis very similar to E. bidentata but can be distinguished from this and other Eutheola species by the sinuate mandibles, carinate frontoclypeal suture, and smaller and more disperse pronotal punctuation. In males the protarsus is not enlarged, and in females, the elytral margin is not thickened as in E. bidentata.

\section{Megasoma elephas (Fabricius, 1775) \\ Figure $4 \mathrm{H}$}

Geographic distribution. Southern Mexico to Venezuela (Morón and Deloya 2001, Ratcliffe and Morón 2005). In Colombia: Antioquia, Córdoba, Magdalena, and Norte de Santander (Restrepo-Giraldo et al. 2003, Neita-Moreno 2011).

Material examined, new record. Colombia, Sucre, Sincelejo, University of Sucre campus $\left(09^{\circ} 18^{\prime} 52^{\prime \prime} \mathrm{N}\right.$, $\left.075^{\circ} 23^{\prime} 18^{\prime \prime} \mathrm{W}\right), 2017 / 11 / 29$, MZUSU E02554 (1ठ).

Identification. Females of this species can be distinguished from other Megasoma species by presenting bright black tegument, completely covered by reddish yellow pubescence, the males with a cephalic horn covered with pubescence, a strong and acuminate horn in anterior angles of pronotum, and a dentate and widely truncated clypeus.

\section{Phileurus didymus (Linnaeus, 1758)}

Figure 4I

Geograpich distribution. Mexico to Paraguay (Endrödi 1978). In Colombia: Amazonas, Antioquia, Atlántico, Boyacá, Cauca, Chocó, Cundinamarca, Tolima, and Valle del Cauca (Restrepo-Giraldo et al. 2003, GarcíaAtencia et al. 2015).

Material examined, new record. Colombia, Sucre, Sincelejo, University of Sucre campus. $\left(09^{\circ} 18^{\prime} 52^{\prime \prime} \mathrm{N}, 075^{\circ}\right.$ 23'18"W). 2015/10/2015, MZUSU E02548 (1ㅇ).

Identification. This species can be distinguished from other Phileurus species by the nearly obsolete basal tooth on the protibia and the stout tooth at apex of metatibia.

\section{Phileurus valgus (Olivier, 1789)}

Figure 4J

Geographic distribution. Southern USA to Argentina and West Indies (Endrodi 1985, Ratcliffe 2011). In Colombia: Antioquia, Casanare, Córdoba, and Valle del Cauca (Restrepo-Giraldo et al. 2003, Pardo-Locarno et al. 2012, Pardo-Locarno 2013).

Material examined, new record. Colombia, Sucre, Sincelejo, University of Sucre campus $\left(09^{\circ} 18^{\prime} 52^{\prime \prime} \mathrm{N}\right.$, 0752'ㄱ'18"W), 2016/05/08, MZUSU E02549 (19). Colombia, Sucre, Sincelejo, University of Sucre campus $\left(09^{\circ} 18^{\prime} 52^{\prime \prime} \mathrm{N}, 075^{\circ} 23^{\prime} 18^{\prime \prime} \mathrm{W}\right), 2016 / 12 / 06$, MZUSU E02550 (1우).

Identification. This species can be distinguished from other Phileurus species by its black tegument with abundant punctures, the quadridentate protibia; and the metatibia with 2 large teeth at apex.

\section{Strategus aloeus (Linnaeus, 1758) \\ Figure 4K}

Geographic distribution. Southern USA to Brazil (Ratcliffe 1976). In Colombia: Amazonas, Antioquia, Atlántico, Boyacá, Caldas, Caquetá, Casanare, Cauca, Chocó, Córdoba, Cundinamarca, Guajira, Guaviare, Huila, Magdalena, Meta, Nariño, Norte de Santander, Quindío, Santander, Sucre, Tolima, Valle del Cauca, Vaupés, and Vichada (Restrepo-Giraldo et al. 2003, Sanabria-García et al. 2012, García-Atencia et al. 2015).

Material examined. Colombia, Sucre, Sincelejo, University of Sucre campus $\left(09^{\circ} 18^{\prime} 52^{\prime \prime} \mathrm{N}, 075^{\circ} 23^{\prime} 18^{\prime \prime} \mathrm{W}\right)$, 2016/05/11, MZUSU E02536-38 (3). Colombia, Sucre, Sincelejo, University of Sucre campus $\left(09^{\circ} 18^{\prime} 52^{\prime \prime} \mathrm{N}, 075^{\circ}\right.$ 23'18"W), 2016/05/14, MZUSU E02539-40 (29).

Identification. Females of this species can be distinguished from other Strategus species by the presence of a fovea in the pronotum that is densely dotted, the protibia with 4 quadridentate projections, and the metatibia with 3 teeth.

\section{Tomarus fossor (Latreille, 1813)}

Figure 4L

Geographic distribution. Antigua, Bahamas, Bolivia, Brazil, Colombia, Cuba, Curaçao, Ecuador, El Salvador, Jamaica, Panama, Puerto Rico, and Venezuela (Endrödi 1969, Ratcliffe 2003, Ratcliffe and Cave 2006, Carvajal et al. 2011). In Colombia: Antioquia, Atlántico, Bolívar, Caldas, Cauca, Cesar, Córdoba, Guajira, Magdalena, and Sucre (Endrödi 1969, Restrepo-Giraldo et al. 2003, LopezGarcia et al. 2015).

Material examined. Colombia, Sucre, Sincelejo, University of Sucre campus $\left(09^{\circ} 18^{\prime} 52^{\prime \prime} \mathrm{N}, 075^{\circ} 23^{\prime} 18^{\prime \prime} \mathrm{W}\right)$, 2016/05/19, MZUSU E02501-02 (29). Colombia, Sucre, Sincelejo, University of Sucre campus $\left(09^{\circ} 18^{\prime} 52^{\prime \prime} \mathrm{N}\right.$,

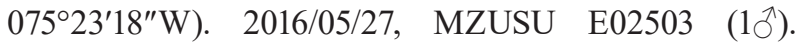
Colombia, Sucre, Sincelejo, University of Sucre campus $\left(09^{\circ} 18^{\prime} 52^{\prime \prime} \mathrm{N}, 075^{\circ} 23^{\prime} 18^{\prime \prime} \mathrm{W}\right), 2016 / 05 / 30 /$, MZUSU E02504-06 (3). Colombia, Sucre, Sincelejo, Uni- 
versity of Sucre campus $\left(09^{\circ} 18^{\prime} 52^{\prime \prime} \mathrm{N}, 075^{\circ} 23^{\prime} 18^{\prime \prime} \mathrm{W}\right)$, 2016/06/08/, MZUSU E02507-08 (29).

Identification. This species can be distinguished from other Tomarus species by its small size, reddish color, pronotum without fovea nor tubercles, and deeper punctuation on pronotum.

\section{Subfamily Melolonthinae}

\section{Liogenys quadridens (Fabricius, 1798)} Figure 4M

Geographic distribution. Brazil, Colombia, Guyana, Panama, and Venezuela (Restrepo-Giraldo et al. 2003, Evans and Smith 2009). In Colombia: Atlántico, Cesar, and Guajira (Restrepo-Giraldo et al. 2003, Pardo-Locarno et al. 2012, García-Atencia et al. 2015, Medina et al. 2018).

Material examined, new record. Colombia, Sucre, Sincelejo, University of Sucre campus $\left(09^{\circ} 18^{\prime} 52^{\prime \prime} \mathrm{N}\right.$, 075²3'18"W). 2015/05/19, MZUSU E02551-52 (2仓ึ), MZUSU E02553 (1우).

Identification. This species can be distinguished from other Liogeneys species by the bicolor body, head and pronotum black and elytra reddish brown; the clypeus with 2 projections similar to teeth; pygidium subquadrate and narrower than the distance between the propygidial spiracles.

\section{Phyllophaga menetriesi (Blanchard, 1850)}

\section{Figure 4N}

Geographic distribution. Colombia, Costa Rica, El Salvador, Guatemala, Honduras, Mexico, Nicaragua, Panama, and Venezuela (Solís and Morón 1998, Evans and Smith 2009). In Colombia: Antioquia, Atlántico, Caldas, Cauca, Huila, Quindío, Risaralda, and Tolima (Pardo-Locarno et al. 2003, Pardo-Locarno and Morón 2006, Pardo-Locarno and Montoya 2007, Vallejo and Wolff 2013, García-Atencia et al. 2015).

Material examined, new record. Colombia, Sucre, Sincelejo, University of Sucre campus $\left(09^{\circ} 18^{\prime} 52^{\prime \prime} \mathrm{N}\right.$,

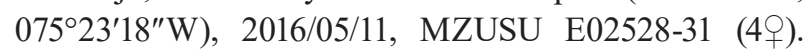
Colombia, Sucre, Sincelejo, University of Sucre campus $\left(09^{\circ} 18^{\prime} 52^{\prime \prime} \mathrm{N}, 075^{\circ} 23^{\prime} 18^{\prime \prime} \mathrm{W}\right), 2016 / 05 / 27$, MZUSU E02532-33 (2), MZUSU E02534 (1ठึ). Colombia, Sucre, Sincelejo, University of Sucre campus $\left(09^{\circ} 18^{\prime} 52^{\prime \prime} \mathrm{N}, 075^{\circ}\right.$ 23'18"W), 2016/03/30, MZUSU E02535 (1우).

Identification. This species can be distinguished of $P$. obsoleta by its thickly setose tegument, the long yellowish setae; elytra brownish or orangish brown.

Subfamily Rutelinae

\section{Anomala valida Burmeister, 1844}

Figure 40

Geographic distribution. Colombia, Costa Rica, Ecuador, Mexico, and Nicaragua (Bates 1887, Flores et al. 2008, Filippini et al. 2017). In Colombia: Córdoba, Risaralda, and Valle del Cauca (Útima and Vallejo 2008,
Pardo-Locarno et al. 2012, Pardo-Locarno et al. 2017).

Material examined, new record. Colombia, Sucre, Sincelejo, University of Sucre campus. $\left(09^{\circ} 18^{\prime} 52^{\prime \prime} \mathrm{N}, 075^{\circ}\right.$ 23'18"W), 2016/05/11, MZUSU E02513 (1ㅇ). Colombia, Sucre, Sincelejo, University of Sucre campus $\left(09^{\circ}\right.$ $\left.18^{\prime} 52^{\prime \prime} \mathrm{N}, 075^{\circ} 23^{\prime} 18^{\prime \prime} \mathrm{W}\right), 2016 / 05 / 19$, MZUSU E02514-15 (2ㅇ), MZUSU E02516 (1 $\overbrace{}^{\Uparrow})$. Colombia, Sucre, Sincelejo, University of Sucre campus $\left(09^{\circ} 18^{\prime} 52^{\prime \prime} \mathrm{N}, 075^{\circ} 23^{\prime} 18^{\prime \prime} \mathrm{W}\right)$, 2016/05/27, MZUSU E02517 (1). Colombia, Sucre, Sincelejo, University of Sucre campus $\left(09^{\circ} 18^{\prime} 52^{\prime \prime} \mathrm{N}\right.$, $\left.075^{\circ} 23^{\prime} 18^{\prime \prime} \mathrm{W}\right), 2016 / 05 / 30$, MZUSU E02518 (1, sex undetermined). Colombia, Sucre, Sincelejo, University of Sucre campus $\left(09^{\circ} 18^{\prime} 52^{\prime \prime} \mathrm{N}, 075^{\circ} 23^{\prime} 18^{\prime \prime} \mathrm{W}\right), 2016 / 06 / 8$, MZUSU E02519-20 (2q).

Identification. This species can be distinguished from other Anomala species by having the protibia with 2 teeth, the pronotum darkish, and the elytral striae with darker punctures.

\section{Leucothyreus cf. femoratus Burmeister, 1844}

Figure 4P

Geographic distribution. Colombia, Costa Rica, Mexico, Nicaragua, Panama, and Venezuela (Bates 1888, Morón 1979, Pardo-Locarno et al. 2006, Morón and Márquez 2012). In Colombia: Antioquia, Boyacá, Cauca, Chocó, Córdoba, Cundinamarca, Huila, Meta, Quindío, Santander, Sucre, Tolima, and Valle del Cauca (RestrepoGiraldo et al. 2003, Pardo-Locarno et al. 2006, Martínez and Plata-Rueda 2013).

Material examined. Colombia, Sucre, Sincelejo, University of Sucre campus $\left(09^{\circ} 18^{\prime} 52^{\prime \prime} \mathrm{N}, 075^{\circ} 23^{\prime} 18^{\prime \prime} \mathrm{W}\right)$, 2016/05/30, MZUSU E02545 (1). Colombia, Sucre, Sincelejo, University of Sucre campus $\left(09^{\circ} 18^{\prime} 52^{\prime \prime} \mathrm{N}, 075^{\circ}\right.$ 23'18"W), 2016/12/01, MZUSU E02546 (1우).

\section{Pelidnota polita (Latreille, 1812)}

Figure 4Q

Geographic distribution. Colombia, Panama, and Venezuela (Soula 2009). In Colombia: Atlántico, Boyacá, Chocó, Cundinamarca, Magdalena, Meta, and Sucre (Neita-Moreno 2011, García-Atencia et al. 2015, LópezGarcía et al. 2015, Taboada-Verona et al. 2016).

Material examined. Colombia, Sucre, Sincelejo, University of Sucre campus $\left(09^{\circ} 18^{\prime} 52^{\prime \prime} \mathrm{N}, 075^{\circ} 23^{\prime} 18^{\prime \prime} \mathrm{W}\right)$, 2016/05/11, MZUSU E02521 (1ㅇ), MZUSU E02522 (1 ^). Colombia, Sucre, Sincelejo, University of Sucre campus $\left(09^{\circ} 18^{\prime} 52^{\prime \prime} \mathrm{N}, 075^{\circ} 23^{\prime} 18^{\prime \prime} \mathrm{W}\right), 2016 / 05 / 14$, MZUSU E02523-24 (2). Colombia, Sucre, Sincelejo, University of Sucre campus $\left(09^{\circ} 18^{\prime} 52^{\prime \prime} \mathrm{N}, 075^{\circ} 23^{\prime} 18^{\prime \prime} \mathrm{W}\right), 2016 / 06 / 08$, MZUSU E02525 (1ㅇ). Colombia, Sucre, Sincelejo, University of Sucre campus $\left(09^{\circ} 18^{\prime} 52^{\prime \prime} \mathrm{N}, 075^{\circ} 23^{\prime} 18^{\prime \prime} \mathrm{W}\right)$, 2016/11/12, MZUSU E02526 (19). Colombia, Sucre, Sincelejo, University of Sucre campus $\left(09^{\circ} 18^{\prime} 52^{\prime \prime} \mathrm{N}, 075^{\circ}\right.$ 23'18"W), 2016/12/09, MZUSU E0227 (1ㅇ).

Identification. This species can be distinguished from other Pelidnota species by the yellow body, and the 
absence of margin on the posterior edge of prothorax. Size between 20 and $28 \mathrm{~mm}$.

\section{Xenopelidnota anomala (Burmeister, 1844)}

Figure 4R

Geographic distribution. Colombia, Bolivia, Trinidad and Tobago, and Venezuela(Peck 2010). In Colombia: Atlántico (García-Atencia et al. 2015).

Material examined, new record. Colombia, Sucre, Sincelejo, University of Sucre campus $\left(09^{\circ} 18^{\prime} 52^{\prime \prime} \mathrm{N}\right.$,

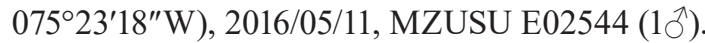

Identification. This species can be distinguished from other Xenopelidnota species by the head and thorax ventrally dark brown with green metallic reflections and finely punctuated; elytra light brown with interstriae with punctuations; protibia with 3 teeth and ventrally with abundant yellowish setae.

Subfamily Aphodiinae

\section{Ataenius gr. carinator}

Figure 5A

Material examined. Colombia, Sucre, Sincelejo, University of Sucre campus $\left(09^{\circ} 18^{\prime} 52^{\prime \prime} \mathrm{N}, 075^{\circ} 23^{\prime} 18^{\prime \prime} \mathrm{W}\right)$, 2016/05/23, MZUSU E02634-35 (2, sex undetermined).

Subfamily Scarabaeinae

\section{Canthidium aurifex Bates, 1887}

Figure 5B

Geographic distribution. Colombia, Costa Rica, Ecuador, Mexico, and Panama (Morón and Aragón 2003, Solís and Kohlmann 2004, Noriega et al. 2013). In Colombia: Antioquia, Bolívar, Cauca, Cesar, Chocó, Córdoba, Magdalena, Meta, Sucre, and Vaupés (Escobar 2000, Noriega 2004, Concha-Lozada et al. 2010, Noriega et al. 2013).

Material examined. Colombia, Sucre, Sincelejo, University of Sucre campus $\left(09^{\circ} 18^{\prime} 52^{\prime \prime} \mathrm{N}, 075^{\circ} 23^{\prime} 18^{\prime \prime} \mathrm{W}\right)$, 2016/05/23, MZUSU E02591-95 (5, sex undetermined), MZUSU E02666 (1, sex undetermined).

Identification. This species can be differentiated from other species of the genus because having 2 teeth on the frontal edge of the head, 3 small conical protuberances in the frontoclypeal area, and interstriae with fine punctures.

\section{Canthon cyanellus LeConte, 1859}

Figure 5C

Geographic distribution. Belize, Brazil, Colombia, Costa Rica, Ecuador, El Salvador, Guatemala, Honduras, Mexico, Nicaragua, Panama, Peru, Trinidad and Tobago, USA, and Venezuela (Horgan 2001, Solís and Kohlmann 2002, Noriega et al. 2013, Latha et al. 2016). In Colombia: Atlántico, Bolívar, Cesar, Chocó, Córdoba, Guajira, Magdalena, Meta, Sucre, and Tolima (Vulcano and Pereira 1964, Navarro et al. 2011, Neita-Moreno 2012, Noriega et al. 2013).

Material examined. Colombia, Sucre, Sincelejo, University of Sucre campus $\left(09^{\circ} 18^{\prime} 52^{\prime \prime} \mathrm{N}, 075^{\circ} 23^{\prime} 18^{\prime \prime} \mathrm{W}\right)$, 2016/05/23, MZUSU E02573-80 (8, sex undetermined).

Identification. The diagnostic characters of the species are the yellow pronotum, with a medial black stripe, and the elytra and pygidium with black margins.

\section{Canthon juvencus Harold, 1868 \\ Figure 5D}

Geographic distribution. Brazil, Colombia, Costa Rica, Panama, Peru, and Venezuela (Solís and Kohlmann 2002, Ratcliffe et al. 2015). In Colombia: Antioquia, Atlántico, Bolívar, Boyacá, Cesar, Chocó, Córdoba, Cundinamarca, Guajira, Guaviare, Magdalena, Meta, Sucre, Tolima, and Vichada (Arias-Buriticá et al. 2011, Noriega et al. 2013, González-Alvarado and Medina 2015) .

Material examined. Colombia, Sucre, Sincelejo, University of Sucre campus $\left(09^{\circ} 18^{\prime} 52^{\prime \prime} \mathrm{N}, 075^{\circ} 23^{\prime} 18^{\prime \prime} \mathrm{W}\right)$, 2016/05/23, MZUSU E02527-33 (7, sex undetermined), MZUSU E02651 (14, sex undetermined).

Identification. This species differs from the other species of Canthon genus by having its body dorsally full of setae and by its small size, between 2 and $5 \mathrm{~mm}$.

\section{Canthon mutabilis Lucas, 1857}

Figure 5E

Geographic distribution. Argentina, Brazil, Colombia, Costa Rica, French Guiana, Panama, Paraguay, Peru, and Venezuela (Solís and Kohlmann 2002). In Colombia: Antioquia, Atlántico, Bolívar, Cesar, Córdoba, Guajira, Magdalena, Meta, Sucre, and Valle del Cauca (Noriega 2004, Navarro et al. 2011, Noriega et al. 2013, Molina et al. 2016).

Material examined. Colombia, Sucre, Sincelejo, University of Sucre campus $\left(09^{\circ} 18^{\prime} 52^{\prime \prime} \mathrm{N}, 075^{\circ} 23^{\prime} 18^{\prime \prime} \mathrm{W}\right)$, 2016/05/23, MZUSU E02581-90 (10, sex undetermined), MZUSU E02660-62 (72, sex undetermined).

Identification. This species can be distinguished from other species of the genus Canthon by its black tegument and the yellow elytra with a black transversal strip located on posterior half.

\section{Deltochilum guildingii (Westwood, 1835)}

Figure 5F

Geographic distribution. Brazil, Colombia, Suriname, Trinidad and Tobago, and Venezuela (González-Alvarado and Vaz-de-Mello 2014). In Colombia: Antioquia, Atlántico, Bolívar, Cesar, Córdoba, Cundinamarca, Magdalena, Meta, and Sucre (Noriega et al. 2013, González-Alvarado and Vaz-de-Mello 2014).

Material examined. Colombia, Sucre, Sincelejo, University of Sucre campus $\left(09^{\circ} 18^{\prime} 52^{\prime \prime} \mathrm{N}, 075^{\circ} 23^{\prime} 18^{\prime \prime} \mathrm{W}\right)$, 2016/05/23, MZUSU E02637 (19). 

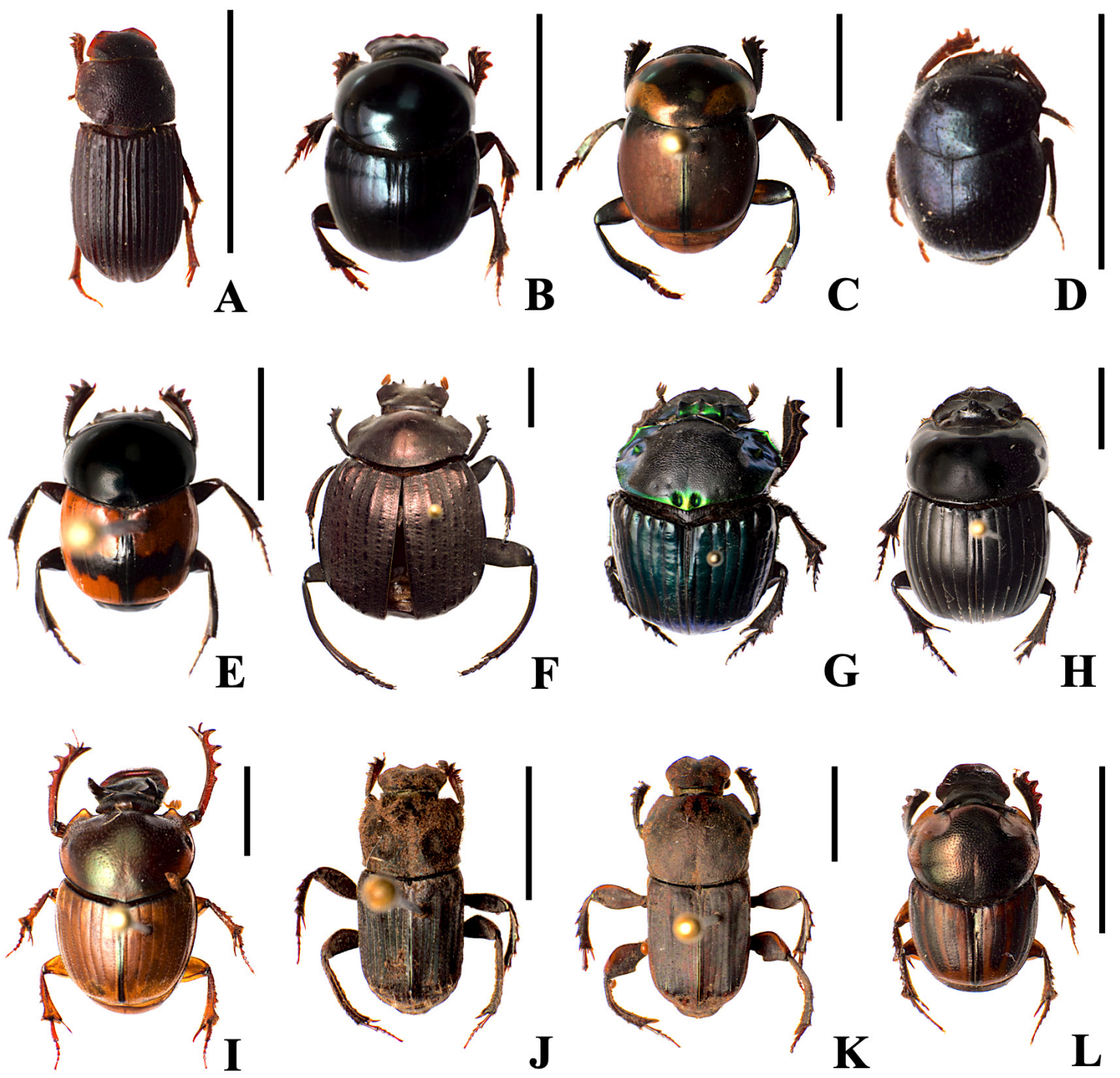

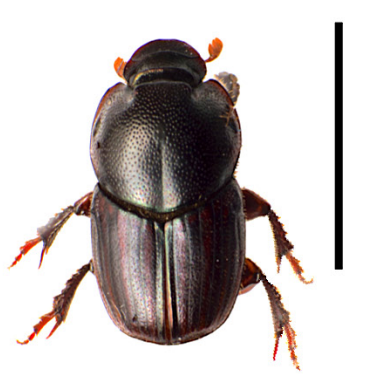

M
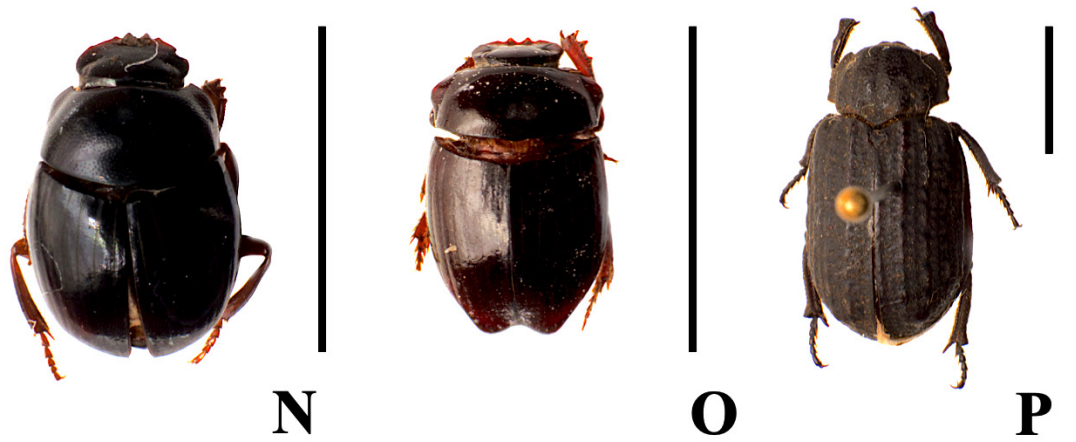

Figure 5. Beetles of superfamily Scarabaeoidea present at the University of Sucre campus. A. Ataenius gr. carinator. B. Canthidium aurifex. C. Canthon cyanellus. D. Canthon juvencus. E. Canthon mutabilis. F. Deltochilum guildingii. G. Diabroctis cadmus. H. Dichotomius aff. agenor. I. Digitonthophagus gazella. J. Eurysternus impressicollis. K. Eurysternus mexicanus. L. Onthophagus marginicollis. M. Onthophagus bidentatus. N. Pseudocanthon aff. perplexus. O. Uroxys cf. deavilai. P. Omorgus suberosus. Scale bars $=1 \mathrm{~cm}$.

Identification. This species can be distinguished from other Deltochilum species by its cupreous body color, the rounded lateral projection of prothorax, and the interstriae punctures of the same size as striae punctures.

Diabroctis cadmus (Harold, 1868)
Figure 5G

Geographic distribution. Colombia and Venezuela (Ferrer-Paris et al. 2013, Noriega et al. 2013). In Colombia: Atlántico, Bolívar, Cesar, Córdoba, Guajira, Magdalena, Meta, and Sucre (Noriega et al. 2013, González-Alvarado and Medina 2015). 
Material examined. Colombia, Sucre, Sincelejo, University of Sucre campus $\left(09^{\circ} 18^{\prime} 52^{\prime \prime} \mathrm{N}, 075^{\circ} 23^{\prime} 18^{\prime \prime} \mathrm{W}\right)$, 2016/05/23, MZUSU E02636 (19).

Identification. This species can be identified by the anterior portion of the pronotal process with an acute lobe on each side and with a transverse and arched carina, and the cephalic process with 3 tubercles.

\section{Dichotomius aff. agenor (Harold, 1869)}

Figure $5 \mathrm{H}$

Material examined. Colombia, Sucre, Sincelejo, University of Sucre campus $\left(09^{\circ} 18^{\prime} 52^{\prime \prime} \mathrm{N}, 075^{\circ} 23^{\prime} 18^{\prime \prime} \mathrm{W}\right)$, 2016/05/23, MZUSU E02638 (1ㅇ), MZUSU E02639 (1ठ̋).

\section{Digitonthophagus gazella (Fabricius, 1787)}

Figure 5I

Geographic distribution. America (Argentina, Bolivia, Brazil, Chile, Colombia, Cuba, Dominican Republic, El Salvador, Guadeloupe, Guatemala, Jamaica, Mexico, Nicaragua, Paraguay, Peru, Puerto Rico, USA, and Venezuela) (Fincher et al. 1983, Miranda et al. 1990, RiveraCervantes and García-R. 1991, Kohlmann 1994, Ripa and Rojas 1995, Maes et al. 1997, Ruiz 2000, Noriega 2002, Ivie and Philips 2008, Vidaurre et al. 2008, Álvarez et al. 2009, Lozano 2010, Noriega et al. 2010, Noriega et al. 2011, Genier and Davis 2017, Pablo-Cea et al. 2017). In Colombia: Antioquia, Atlántico, Bolívar, Boyacá, Caldas, Casanare, Cesar, Córdoba, Cundinamarca, Guajira, Magdalena, Meta, San Andrés Isla, Santander, Sucre, Tolima, Valle del Cauca, and Vichada (Noriega 2002, Noriega et al. 2011, Noriega et al. 2013, GonzálezAlvarado and Medina 2015).

Material examined. Colombia, Sucre, Sincelejo, University of Sucre campus $\left(09^{\circ} 18^{\prime} 52^{\prime \prime} \mathrm{N}, 075^{\circ} 23^{\prime} 18^{\prime \prime} \mathrm{W}\right)$, 2016/05/23, MZUSU E02644 (1ㅇ), MZUSU E02645 (1ठْ).

Identification. The diagnostic characters of the species are its size from 10 to $12 \mathrm{~mm}$, short horns which are abruptly narrowed apically, short protibia with the external teeth more robust. It is the only species of this genus recorded from Colombia.

\section{Eurysternus impressicollis Castelnau, 1840 Figure 5J}

Geographic distribution. Brazil, Colombia, and Venezuela (Génier 2009, Camero-Rubio 2010, Lozano 2010). In Colombia: Amazonas, Antioquia, Arauca, Atlántico, Bolívar, Caldas, Caquetá, Cesar, Córdoba, Cundinamarca, Guainía, Guajira, Magdalena, and Sucre (Camero-Rubio 2010, Noriega et al. 2013, González-Alvarado and Medina 2015).

Material examined. Colombia, Sucre, Sincelejo, University of Sucre campus $\left(09^{\circ} 18^{\prime} 52^{\prime \prime} \mathrm{N}, 075^{\circ} 23^{\prime} 18^{\prime \prime} \mathrm{W}\right)$, 2016/05/23, MZUSU E02566-72 (7, sex undetermined), MZUSU E02653 (6, sex undetermined).

Identification. This species belongs to the impressicollis group and is distinguished by the pronotal surface with depressions or roughness, elytra with well-defined striae, and strongly developed apical tubercle at the third interstriae.

\section{Eurysternus mexicanus Harold, 1869}

Figure 5K

Geographic distribution. Belize, Colombia, Costa Rica, Guatemala, Guyana, Honduras, Mexico, Nicaragua, Panama, Trinidad and Tobago, and Venezuela (Génier 2009). In Colombia: Antioquia, Atlántico, Bolívar, Boyacá, Caldas, Cesar, Córdoba, Guajira, Magdalena, Meta, Norte de Santander, Risaralda, Santander, Sucre, Tolima, and Valle del Cauca (Camero-Rubio 2010, Noriega et al. 2013, Pardo-Locarno and Camero 2014).

Material examined. Colombia, Sucre, Sincelejo, University of Sucre campus $\left(09^{\circ} 18^{\prime} 52^{\prime \prime} \mathrm{N}, 075^{\circ} 23^{\prime} 18^{\prime \prime} \mathrm{W}\right)$, 2016/05/23, MZUSU E02555-65 (11, sex undetermined), MZUSU E02654-56 (9, sex undetermined).

Identification. This species can be distinguished from other Eurysternus species by having several calli in the pronotal surface, of which only 3 of them are in the anteromedial area and are smooth.

\section{Onthophagus marginicollis Harold, 1880}

Figure 5L

Geographic distribution. Bolivia, Brazil, Colombia, Costa Rica, Cuba, Ecuador, El Salvador, French Guiana, Guatemala, Mexico, Nicaragua, Panama, Peru, and Venezuela (Kohlmann and Solís 2001, Pulido-Herrera and Zunino 2007, Lozano 2010, Villamarín-Cortez 2010, Ratcliffe et al. 2015). In Colombia: Atlántico, Bolívar, Caldas, Cesar, Chocó, Córdoba, Cundinamarca, Guajira, Huila, Magdalena, Meta, Sucre, Tolima, Valle del Cauca, Vaupés, and Vichada (Howden and Young 1981, Medina and Pulido 2009, Arias-Buriticá et al. 2011, Noriega et al. 2013, Pardo-Locarno and Camero 2014, GonzálezAlvarado and Medina 2015).

Material examined. Colombia, Sucre, Sincelejo, University of Sucre campus $\left(09^{\circ} 18^{\prime} 52^{\prime \prime} \mathrm{N}, 075^{\circ} 23^{\prime} 18^{\prime \prime} \mathrm{W}\right)$, 2016/05/23, MZUSU E02596-99 (4ㅇ), MZUSU E0260002 (3ð), MZUSU E02657 (4○), MZUSU E02658-59 (48ㅇ).

Identification. This species is distinguished from other species of the genus Onthophagus by having the elytra with yellow striae and interstriae area and the epipleuron and some interstriae brown-black.

\section{Onthophagus bidentatus Drapiez, 1819}

Figure 5M

Geographic distribution. Argentina, Brazil, Colombia, French Guiana, Peru, Trinidad and Tobago, and Venezuela (Pulido-Herrera and Zunino 2007, Ratcliffe et al. 2015). In Colombia: Amazonas, Casanare, and Vichada (Vulcano and Pereira 1967, Medina and Pulido 2009).

Material examined. Colombia, Sucre, Sincelejo, University of Sucre campus $\left(09^{\circ} 18^{\prime} 52^{\prime \prime} \mathrm{N}, 075^{\circ} 23^{\prime} 18^{\prime \prime} \mathrm{W}\right)$, 
2016/05/23, MZUSU E02603-06 (4ㅇ), MZUSU E0260716 (10ð), MZUSU E02663-64 (45ㅇ), MZUSU E02665 $\left(13 \jmath^{\Uparrow}\right)$

Identification. This species can be distinguished of $O$. marginicollis by having a completely dark, black epipleurum.

\section{Pseudocanthon aff. perplexus (LeConte, 1847)}

Figure $5 \mathrm{~N}$

Material examined. Colombia, Sucre, Sincelejo, University of Sucre campus $\left(09^{\circ} 18^{\prime} 52^{\prime \prime} \mathrm{N}, 075^{\circ} 23^{\prime} 18^{\prime \prime} \mathrm{W}\right)$, 2016/05/23, MZUSU E02617-26 (10, sex undetermined), MZUSU E02647-50 (135, sex undetermined).

\section{Uroxys cf. deavilai Delgado \& Kohlmann 2007} Figure 50

Geographic distribution. Colombia, Costa Rica, El Salvador, Guatemala, Mexico, and Nicaragua (Solís and Kohlmann 2013, Pablo-Cea et al. 2016, Rangel-Acosta et al. 2016). In Colombia: Atlántico and Cesar (Martínez Hernandez et al. 2012, Rangel-Acosta et al. 2016).

Material examined. Colombia, Sucre, Sincelejo, University of Sucre campus $\left(09^{\circ} 18^{\prime} 52^{\prime \prime} \mathrm{N}, 075^{\circ} 23^{\prime} 18^{\prime \prime} \mathrm{W}\right)$, 2016/05/23, MZUSU E02640-43 (4, sex undetermined), MZUSU E02652 (5, sex undetermined).

Family Trogidae

Subfamily Troginae

\section{Omorgus suberosus (Fabricius, 1775)}

Figure 5P

Geographic distribution. America (Argentina, Brazil, Chile, Colombia, Costa Rica, Ecuador, Guatemala, Panama, Paraguay, Peru, Mexico, Nicaragua, and Venezuela) (Scholtz 1990, Deloya 2000, Ratcliffe 2002, Aballay et al. 2008, Diéguez 2008, Correa et al. 2013, Baena et al. 2015, Salazar and Donoso 2015). In Colombia: Atlántico, Cesar, Chocó, Cundinamarca, Magdalena, and Norte de Santander (Scholtz 1990, Neita-Moreno 2011).

Material examined, new record. Colombia, Sucre, Sincelejo, University of Sucre campus $\left(09^{\circ} 18^{\prime} 52^{\prime \prime} \mathrm{N}\right.$, $\left.075^{\circ} 23^{\prime} 18^{\prime \prime} \mathrm{W}\right)$, 2016/05/23, MZUSU E02646 (1ㅇ).

Identification. This species can be distinguished from the other Omorgus species by its 10-segmented antennae and a 3-segmented club, an abdomen with 5 visible sternites, the pygidium covered by the elytra, the elytra with a rough appearance and protruding longitudinally arranged tubercles.

\section{Discussion}

Geographical isolation and the absence of connectivity between vegetation patches in urban areas makes the gene flow difficult between populations and puts at risk species survival (Laita et al. 2011). However, much of the university's campus is surrounded by green areas and far from traffic, noise, and excessive pollution, which may have contributed to the continuity and interaction between resident species. Despite limited vegetation cover, the presence of a large number of species gives evidence for the potential exploitation of woodland remnants. In addition, beetles have formidable dispersion capacity and are highly mobile in their search for trophic resources and in their recolonization of perturbed habitats, such as after fire or pesticide use (Driscoll and Weir 2005).

We found that the most species-rich subfamily on campus was the Scarabaeinae. This might be due in large part because of the high efficiency of traps used in their capture (Ferrer-Paris et al. 2013). The species of Scarabaeinae are multivoltine, and present an active reproductive cycle throughout the year in contrast to the univoltine Cetoniinae, Dynastinae, Melolonthinae, and Rutelinae (Morón et al. 1985); this differentiation may explain the low richness and abundance of individuals belonging to the non-scarabaeine subfamilies, as the sampling period probably did not coincide in time with their moments of their peak abundance. All species of Scarabaeinae that were found in this survey had been recorded before in the Colombian Tropical Dry Forest and constitute only the $13 \%$ of all the species reported for the Caribbean region in Colombia (Noriega et al. 2013). The genera presenting the highest species richness were Canthon Hoffmannsegg, 1817 and Onthophagus Latreille, 1802, a trend that is repeated throughout the Colombian Tropical Dry Forest (Martinez et al. 2009, 2010, Noriega et al. 2016) both in native forests and lands used for agriculture and livestock. Some of the captured species are representative of the Tropical Dry Forest and restricted to northern Colombia, such as E. impresicollis and D. cadmus (Medina et al. 2001, Camero-Rubio 2010). While D. cadmus is primarily associated to bovine excrement, we found this species in traps baited with human dung, which suggests that this species exploits this potential resource. We also confirm the presence of the invasive species D. gazella in the Sucre Department, which was anteriorly reported in the municipality of Colosó by Navarro et al. (2009). Thus, this species appears to have effectively expanded its distribution from livestock areas to the urban area of Sincelejo and our data corroborates the high adaptability of D. gazella (Noriega et al. 2011).

The species of the family Passalidae found in our study represent $16 \%$ of those known for Caribbean Colombian (Jiménez-Ferbans and Amat-García 2009, Jiménez-Ferbans et al. 2012) and 100\% of those reported in Sucre Department (Jiménez-Ferbans and Amat-García 2009). Passalids are widespread throughout North and South America and present high adaptability to a range of temperature and humidity conditions; they frequently inhabit dry habitats and low elevation areas (Reyes-Castillo 1970, Pardo-Locarno et al. 2000, AmatGarcía and Reyes-Castillo 2007).

The Melolonthinae found in this study increases the number of genera known for this subfamily in Sucre 
Department; there has not been an inventory of melolonthine species for this part of Colombia. Currently, the only publications are those by Pardo-Locarno et al. (2012) in Caribbean Colombia and some nationwide surveys and taxonomic revisions twhich include some records for this department (Restrepo-Giraldo et al. 2003, Suárez and Amat-García 2007, Gasca-Álvarez and Amat-García 2010, Sanabria-García et al. 2012, LópezGarcía et al. 2015). For the Rutelinae, we provide the second record from Colombia of Xenopelidnota anomala, which was previously identified from the Atlántico Department (García-Atencia and Martínez-Hernández 2015); this confirms the idea proposed by García-Atencia and Martínez-Hernández (2015) concerning the presence and distribution of this species in dry forest fragments of Caribbean Colombia. We also recorded the presence of Megasoma elephas, also known as elephant beetle. The genus Megasoma contains species of large size in Central and South America (Christiansen 2006), and they possess life cycles of extended duration, going from the larval to the adult stage within 2 or 3 years (Morón and Deloya 2001). They spend the greater part of their life cycle in trees and in decomposing wood (Ratcliffe and Morón 2005).

The high number of species collected and their trophic group composition suggest that green areas within urban zones serve as refuges for numerous taxonomic groups. The campus of the University of Sucre is a faunistic refuge for the superfamily Scarabaeoidea within the urban area of Sincelejo. Our study builds upon existing knowledge and the species inventory for this superfamily within Sucre Department. However, we recommend that sampling is continued and intensified in other urban areas during different seasons and using different types of traps and baits. It is very probable that this species-richness of this superfamily will be increased at the regional level if such sampling were undertaken.

\section{Acknowledgements}

We thanks Jhon Cesar Neita (Alexander von Humboldt Institute) for his help in the identification and revision of melolonthine specimens, and Matthias Seidel, Lukasz Minkina, and Michele Rossini for their valuable help in the taxonomical confirmation of some specimens. We also acknowledge the help of Javier Santos and David Morris for kindly checking the English version of the manuscript. We are grateful to the comments and suggestions of 2 anonymous reviewers and the editors that improved the quality of the paper.

\section{Authors' Contributions}

CTV, CSC, OSS collected the data and CTV, CSC and JAN made the analysis and wrote the text. All the authors checked and approved the last version of the manuscript.

\section{References}

Aballay FH, Murúa AF, Acosta JC, Centeno N (2008) Primer registro de artropodofauna cadavérica en sustratos humanos y animales en San Juan, Argentina. Revista de la Sociedad Entomológica Argentina 67 (3-4): 157-163.

Aguilera M (2005) La Economía del Departamento de Sucre: Ganadería y Sector Público. Banco de la República, Centro de Estudios Económicos Regionales, Bogotá, 125 pp.

Álvarez MC, Damborsky MP, Bar ME, Ocampo FC (2009) Registros y distribución de la especie afroasiática Digitonthophagus gazella (Coleoptera: Scarabaeidae: Scarabaeinae) en Argentina. Revista de la Sociedad Entomológica Argentina 68 (3-4): 373-376.

Amat-García G, Blanco-Vargas E, Reyes-Castillo P (2004) Lista de especies de los escarabajos pasálidos (Coleoptera: Passalidae) de Colombia. Revista Biota Colombiana 5: 173-182.

Amat-García G, Reyes-Castillo P (2007) Los Passalidae (Coleoptera: Scarabaeoidea) del departamento del Amazonas, Colombia. Caldasia 29 (2): 329-354.

Amat-García G, Trujillo D (2004) Escarabajos (Coleoptera: Scarabaeoidea) en el Chocó biogeográfico. In: Rangel-Ch JO (Ed.) Colombia Diversidad Biológica IV El chocó Biogeográfico/Costa Pacífica. Universidad Nacional de Colombia, Bogotá, 745-754.

Arias-Buriticá JA, Delgado-Gómez P, González FA, Vaz-de-Mello FZ (2011) Nuevos registros de escarabajos coprófagos (Coleoptera: Scarabaeidae: Scarabaeinae) para el departamento de Chocó (Colombia). Acta Zoológica Mexicana 27 (3): 875-878. https:// doi.org/10.21829/azm.2011.273792

Arrow GJ (1907) A contribution to the classification of the coleopterous family Passalidae. Transactions of the Entomological Society of London 54: 441-469.

Baena ML, Escobar F, Halffter G, García-Chávez JH (2015) Distribution and feeding behavior of Omorgus suberosus (Coleoptera: Trogidae) in Lepidochelys olivacea turtle nests. PloS ONE 10 (9): e0139538. https://doi.org/10.1371/journal.pone.0139538

Bates HW (1887) Biologia Centrali-Americana. Insecta. Coleoptera : Lamellicornia (Copridae, Aphodiidae, Orphnidae, Hybosoridae, Geotrupidae, Trogidae, Aclopidae, Chasmatopteridae, Melolonthidae). Vol. II. (Porter RH, Ed.) Taylor and Francis, London, 25-160.

Bates HW (1888) Pectinicornia and Lamellicornia. Biologia CentraliAmericana, Zoología. Insecta Coleoptera vol. II, part 2. Taylor and Francis, London, 432 pp.

Cambra RA (2006) Diversidad de escarabajos peloteros (Coleoptera: Scarabaeidae: Scarabaeinae) del Parque Nacional Darien, Panamá. Scientia 21 (1): 105-111.

Camero-Rubio E (2010) Los escarabajos del género Eurysternus Dalman, 1824 (Coleoptera: Scarabaeidae) de Colombia. Boletín de la Sociedad Entomológica Aragonesa 46: 147-179.

Carvajal V, Villamarín C, Ortega AM (2011) Escarabajos del Ecuador. Principales géneros. Serie Entomología, No. 1. Instituto de Ciencias Biológicas, Escuela Politécnica Nacional, Quito, 350 pp.

Chalumeau F (1978) Contribution à l'étude des Scarabaeoidea des Antilles. (II. Remarques et observations, description de nouveaux taxa). Bulletin de la Société Entomologique de Mulhouse 1978: 41-56.

Christiansen P (2006) Somatic proportions in genus Megasoma (Scarabaeidae: Dynastinae): Megasoma actaeon. Annals of the Entomological Society of America 99 (2): 342-351. https://doi.org/ 10.1603/0013-8746(2006)099[0342:SPIGMS]2.0.CO;2

Concha-Lozada C, Gallego MC, Pardo-Locarno LC (2010) Fragmentación de ecosistemas montanos e impactos estructurales y poblacionales sobre la comunidad de escarabajos coprófagos (Col.: Scarabaeinae) en el Alto Río Cauca, Popayán, Colombia. Boletín Científico Centro de Museos Museo de Historia Natural 14 (1): 43-55.

Correa C, Puker A, Korasaki V, Ferreira KR (2013) Omorgus suberosus and Polynoncus bifurcatus (Coleoptera: Scarabaeoidea: Trogi- 
dae) in exotic and native environments of Brazil. Zoologia 30 (2): 238-241. https://doi.org/10.1590/S1984-46702013000200015

Delgado-Gómez P, Lopera A, Rangel JO (2012) Variación espacial del ensamblaje de escarabajos coprófagos (Scarabaeidae: Scarabaeinae) en remanentes de bosque seco en Chimichagua (Cesar, Colombia). Colombia Diversidad Biótica XII: La Región Caribe de Colombia: 833-849.

Delgado L, Márquez J (2006) Estado del conocimiento y conservación de los coleópteros Scarabaeoidea (Insecta) del estado de Hidalgo, México. Acta Zoológica Mexicana 22 (2): 57-108.

Deloya C (2000) Distribución de la familia Trogidae en México (Coleoptera lamellicornia). Acta Zoológica Mexicana 81: 63-76.

Diéguez VM (2008) Conocimiento actual de los Trogidae de Chile (Coleoptera: Scarabaeoidea). Revista Chilena de Entomología 34 $11-28$.

Driscoll DA, Weir T (2005) Beetle responses to habitat fragmentation depend on ecological traits, habitat condition, and remnant size. Conservation Biology 19 (1): 182-194. https://doi.org/10.1111/ j.1523-1739.2005.00586.x

Endrödi S (1969) Monographie der Dynastinae. 4. Tribus: Pentodontini (Coleoptera, Lamellicornia). Entomologische Abhandlungen Museum fur Tierkunde, Dresden 37: 1-145.

Endrödi S (1978) Monographie der Dynastinae 8. Tribus: Phileurini, amerikanische Arten II. (Coleoptera). Folia Entomologica Hungarica 31: 85-164.

Endrödi S (1985) The Dynastinae of the world. Springer, Amsterdam, $800 \mathrm{pp}$.

Escobar F (2000) Diversidad y distribución de los escarabajos de estiércol (Coleoptera: Scarabaeidae: Scarabaeinae) de Colombia. Villa de Leyva, Memorias 1er Taller Iberoamericano PrIBES 2000, 197-210

Evans AV, Smith AB (2009) An electronic checklist of the new world chafers (Coleoptera: Scarabaeidae: Melolonthinae). Version 3. http://www-museum.unl.edu/research/entomology/SSSA/nw melos.htm. Accessed on: 2018-3-15.

Fattorini S (2011) Insect extinction by urbanization: a long-term study in Rome. Biological Conservation 144 (1): 370-375. https://doi org/10.1016/j.biocon.2010.09.014

Ferrer-Paris JR, Sánchez-Mercado A, Rodríguez JP (2013) Optimización del muestreo de invertebrados tropicales: Un ejemplo con escarabajos coprófagos (Coleoptera: Scarabaeinae) en Venezuela. Revista de Biología Tropical 61 (1): 89-110.

Filippini V, Micó E, Galante E (2016) Checklist and identification key of Anomalini (Coleoptera, Scarabaeidae, Rutelinae) of Costa Rica. ZooKeys 621: 63-136. https://doi.org/10.3897/zoo keys.621.7565

Filippini V, Onore G, Guidolin L (2017) Larval and pupal descriptions of Anomalini (Coleoptera: Scarabaeidae: Rutelinae) species from Ecuador. Zootaxa 4227: 196-218. https://doi.org/10.11646/ zootaxa.4227.2.3

Fincher GT, Stewart TB, Hunter JS (1983) The 1981 distribution of Onthophagus gazella Fabricius from releases in Texas and Onthophagus taurus Schreber from an unknown release in Florida (Coleoptera: Scarabaeidae). The Coleopterists Bulletin 37: 159-163.

Fisher BL (1998) Insect behavior and ecology in conservation: preserving functional species interactions. Annals of the Entomological Society of America 91 (2): 155-158. https://oi.org/10.1093/ aesa/91.2.155

Flores CP, Ramírez AEC, Morón MA, Gómez BG (2008) Fauna de escarabajos melolóntidos (Coleoptera: Scarabaeoidea) en el muni- cipio de Villaflores, Chiapas, México. Acta Zoológica Mexicana 24: 139.

Fuentes-Medina P, Camero-Rubio E (2009) Estudio de la fauna de escarabajos coprófagos (Coleoptera: Scarabaeidae) en un Bosque Húmedo Tropical de Colombia. Entomotropica 21 (3): 133-143.

García-Atencia S, Martínez-Hernández N, Pardo-Locarno LC (2015) Escarabajos fitófagos (Coleoptera: Scarabaeidae) en un fragmento de bosque seco tropical del departamento del Atlántico, Colombia. Revista Mexicana de Biodiversidad 86 (3): 754-763. https://doi.org/10.1016/j.rmb.2015.07.009

Gasca-Álvarez HJ, Amat-García G (2010) Synopsis and key to the genera of Dynastinae (Coleoptera, Scarabaeoidea, Scarabaeidae) of Colombia. Current advances in Scarabaeoidea research. ZooKeys 34: 153-192. https://doi.org/10.3897/zookeys.34.309

Génier F (2009) Le genre Eurysternus Dalman, 1824 (Scarabaeidae: Scarabaeinae: Oniticellini): révision taxonomique et clés de détermination illustrées. Pensoft, Sofia, $401 \mathrm{pp}$

Genier F, Davis AL (2017) Digitonthophagus gazella auctorum: an unfortunate case of mistaken identity for a widely introduced species (Coleoptera: Scarabaeidae: Scarabaeinae: Onthophagini). Zootaxa 4221 (4): 497-500. https://doi.org/10.11646/ zootaxa.4221.4.8

González-Alvarado A, Medina CA (2015) Listado de especies de escarabajos coprófagos (Coleoptera: Scarabaeidae: Scarabaeinae) de bosque seco de Colombia. Biota Colombiana 16 (1): 36-44.

González-Alvarado A, Vaz-de-Mello FZ (2014) Taxonomic review of the subgenus Hybomidium Shipp 1897 (Coleoptera: Scarabaeidae: Scarabaeinae: Deltochilum). Annales de la Société Entomologique de France 50 (3-4): 431-476. https://doi.org/10.1080/ 00379271.2014 .989178

Grebennikov VV, Scholtz CH (2004) The basal phylogeny of Scarabaeoidea (Insecta: Coleoptera) inferred from larval morphology. Invertebrate Systematics 18 (3): 321-348. https://doi.org/10.1071/ IS03013

Grove SJ (2002) Saproxylic insect ecology and the sustainable management of forests. Annual Review of Ecology and Systematics 33 (1): 1-23. https://doi.org/10.1146/annurev.ecolsys.33.010802.150507

Hincks WD, Dibb JR (1935) Passalidae. In: Junk W (Ed.) Coleopterorum Catalogus. W. Junk, The Hague, 118 pp.

Holdridge L (1979) Ecología basada en zonas de vida. Instituto Interamericano de Ciencias Agrícolas, San José de Costa Rica, 216 pp.

Horgan FG (2001) Burial of bovine dung by coprophagous beetles (Coleoptera: Scarabaeidae) from horse and cow grazing sites in El Salvador. European Journal of Soil Biology 37 (2): 103-111.

Howden HF, Young OP (1981) Panamanian Scarabaeinae: taxonomy, distribution, and habits (Coleoptera, Scarabaeidae). Contributions of the American Entomological Institute 18 (1): 1-204.

Ivie M, Gillogly A (1998) Passalidae of the West Indies. http:// virgin.msu.montana.edu/WestIndies/Polyphaga/Scarabaeoidea/ WIPasslist.html. Accessed on: 2019-3-30.

Ivie MA, Philips TK (2008) Three new species of Canthonella Chapin from Hispaniola, with new records and nomenclatural changes for West Indian dung beetles (Coleoptera: Scarabaeidae: Scarabaeinae). Zootaxa 1701: 1-14. https://doi.org/10.5281/zenodo.180818

Jiménez-Ferbans L, Amat-García G (2009) Sinopsis de los Passalidae (Coleoptera: Scarabaeoidea) del Caribe colombiano. Caldasia 31 (1): 155-173.

Jiménez-Ferbans L, Amat-García G (2010) Clave para los géneros y epecies de Passalidae (Coleoptera: Scarabaeoidea) del Caribe colombiano. Intropica 5: 57-62.

Jiménez-Ferbans L, Amat-García G, Reyes-Castillo P (2012) Nueva especie de Passalus Fabricius, 1792 (Coleoptera: Scarabaeoidea: Passalidae) de la Sierra Nevada de Santa Marta, Colombia. Acta Zoológica Mexicana 28 (3): 607-612.

Jiménez-Ferbans L, Reyes-Castillo P, Schuster J (2015) Passalidae (Coleoptera: Scarabaeoidea) of the Greater and Lesser Antilles. Zootaxa 3956 (4): 491-512. https://doi.org/10.11646/zootaxa.3956.4.3 
Juárez G, González U, 13(2). (2017) Primer registro de Gymnetis stellata Latreille, 1833 (Scarabaeidae: Cetoniinae) para Perú. The Biologist 13 (2): 193-199.

Kohlmann B (1994) A preliminary study of the invasion and dispersal of Digitontophagus gazella (Fabricius, 1787) in México (Coleoptera: Scarabaeidae: Scarabaeinae). Acta Zoológica Mexicana 61: 35-42.

Kohlmann B, Solís A (1997) El género Dichotomius (Coleoptera: Scarabaeidae) en Costa Rica. Giornale Italiano di Entomologia 8 (47): 343-382.

Kohlmann B, Solís A (2001) El género Onthophagus (Coleoptera: Scarabaeidae) en Costa Rica. Giornale Italiano di Entomologia 49 (9): 159-261.

Laita A, Kotiaho J, Mönkkönen M (2011) Graph-theoretic connectivity measures: what do they tell us about connectivity? Landscape Ecology 26 (7): 951-967. https://doi.org/10.1007/s10980-0119620-4

Latha T, Huang P, Perez GA, Paquiul IO (2016) Dung beetle assemblage in a protected area of Belize: A study on the consequence of forest fragmentation and isolation. Journal of Entomology and Zoology studies 4 (1): 457-463.

López-García MM, García-Atencia S, Amat-García G (2015) Escarabajos fitófagos (Coleoptera: Scarabaeidae "Pleurosticti") de los Andes Orientales de Colombia (Departamentos de Santander, Boyacá y Cundinamarca). Boletín Científico Centro de Museos Museo de Historia Natural 19 (2): 322-358.

Lopez-Garcia MM, Gasca-Álvarez HJ, Amat-García G (2015) The scarab beetle tribe Pentodontini (Coleoptera: Scarabaeidae: Dynastinae) of Colombia: taxonomy, natural history, and distribution. Zootaxa 4048 (4): 451-492. http://dx.doi.org/10.11646/ zootaxa.4048.4.1

López-Guerrero I (2005) Los Dichotomius (Coleoptera: Scarabaeidae, Dichotomiini) de la fauna de Mexico Boletín Sociedad Entomológica Aragonesa 1 (36): 195-209.

Lovett GM, Tear TH, Evers DC, Findlay SE, Cosby BJ, Dunscomb JK, Driscoll CT, Weathers KC (2009) Effects of air pollution on ecosystems and biological diversity in the eastern United States. Annals of the New York Academy of Sciences 1162 (1): 99-135. https://doi.org/10.1111/j.1749-6632.2009.04153.x

Lozano C (2010) Nuevos registros de escarabajos coprófagos para la Orchila, Sierra de Perijá, Venezuela. Boletín del Centro de Investigaciones Biológicas 44 (1): 83-89.

Maes JM, Orozco J (2017) Catalogo ilustrado de los Cetoniinae y Trichiinae (Coleoptera: Scarabaeidae) de Nicaragua. Revista Nicaragüense de Entomología 120: 1-111.

Maes JM, Ratcliffe BC, Jameson ML (1997) Fauna entomológica de la Reserva Natural Bosawas, Nicaragua. XI. Escarabajos (Coleoptera: Scarabaeidae) nuevos para la fauna de Nicaragua. Revista Nicaragüense Entomológica 39: 41-45.

Martínez NJ, Cañas LM, Rangel JL, Barraza JM, Montes J, Blanco OR (2010) Coleópteros coprófagos (Scarabaeidae: Scarabaeinae) en un fragmento de bosque seco tropical en el departamento de Atlántico, Colombia. Boletín del Museo de Entomología de la Universidad del Valle 11 (1): 21-30.

Martinez NJ, García H, Pulido L, Ospino D, Narvaez J (2009) Escarabajos Coprófagos (Coleoptera: Scarabaeinae) de la Vertiente Noroccidental, Sierra Nevada De Santa Marta, Colombia. Neotropical Entomology 38 (6): 708-715. https://doi.org/10.1590/ S1519-566X2009000600002

Martínez Hernandez N, Sierra Quintero K, Barraza Méndez J (2012) Escarabajos coprófagos (Coleoptera: Scarabaeinae) asociados a excrementos de mamíferos en un fragmento de bosque seco tropical en el Departamento del Atlántico, Colombia. Ecología Austral 22: 203-210.

Martínez LC, Plata-Rueda A (2013) Some biological aspects of Leucothyreus femoratus (Burmeister) (Coleoptera, Scarabaeidae), in oil palm plantations from Colombia. Journal of Entomological and Acarological Research 41 (1): 27-32.
McDonnell MJ, Pickett ST (1990) Ecosystem structure and function along urban-rural gradients: an unexploited opportunity for ecology. Ecology 71 (4): 1232-1237. https://doi.org/10.2307/1938259

McIntyre NE (2000) Ecology of urban arthropods: a review and a call to action. Annals of the Entomological Society of America 93 (4): 825-835. https://doi.org/10.1603/0013-8746(2000)093[0825:EOU AAR]2.0.CO;2

McKinney ML (2008) Effects of urbanization on species richness: a review of plants and animals. Urban Ecosystems 11 (2): 161-176. https://doi.org/10.1007/s11252-007-0045-4

Medina CA, González-Alvarado A, Neita JC (2018) Caracterización preliminar de escarabajos coprófagos y fitófagos (Coleoptera: Scarabaeidae, Melolonthidae) del bosque seco de la serranía de la Macuira, Alta Guajira, Colombia. Cuadernos de Biodiversidad 54: 28-40.

Medina CA, Lopera A (2000) Clave ilustrada para la identificación de géneros de escarabajos coprófagos (Coleoptera: Scarabaeinae) de Colombia. Caldasia 22: 299-315.

Medina CA, Lopera-Toro A, Vítolo A, Gill B (2001). Escarabajos coprófagos (Coleoptera: Scarabaeidae: Scarabaeinae) de Colombia. Biota Colombiana 2 (2): 131-144.

Medina CA, Pulido LA (2009) Escarabajos coprófagos (Coleoptera: Scarabaeinae) de la Orinoquía colombiana. Biota Colombiana 10: $55-62$.

Miranda CHB, do Nacimiento YA, Bianchin I (1990) Desenvolvimiento de um programa integrado de controle dos nematodeos e a mosca-dos-chifres na região dos cerrados. Fase 3. Potencial de Onthophagus gazellano enterrio de Fezes bovinas. Embrapa Gado de Corte 42: 1-5.

Molina SM, López LMI, González JL (2016) Escarabajos coprófagos (Scarabaeidae: Scarabaeinae) de la Cuenca del Río Dagua, Valle del Cauca, Colombia. Dugesiana 23 (2): 125-133.

Morón M, Aragón A (2003) Importancia ecológica de las especies americanas de Coleoptera Scarabaeoidea. Dugesiana 10 (1): 13-29.

Morón MA (1979) Fauna de coleópteros Lamelicornios de la Estación de Biología Tropical UNAM "Los Tuxtlas", Ver. México. Anales del Instituto de Biología, Universidad Nacional Autónoma de México, Serie Zoología 50: 375-454.

Morón MA, Deloya C (2001) Observaciones sobre el ciclo de vida de Megasoma elephas elephas (Fabricius) (Coleoptera: Melolonthidae: Dynastinae). Folia Entomológica Mexicana 40 (2): 233-244.

Morón MÁ, Márquez J (2012) Nuevos registros estatales y nacionales de escarabajos (Coleoptera: Scarabaeoidea) y comentarios sobre su distribución. Revista Mexicana de Biodiversidad 83 (3): 698-711.

Morón M, Villalobos F, Deloya C (1985) Fauna de coleópteros lamelicornios de Boca del Chajul, Chiapas, México. Folia Entomológica Mexicana 66: 57-118.

Navarro L, Roman K, Gómez H, Pérez A (2009) Primer registro de Digitonthophagus gazella (Fabricius, 1787) para el Departamento de Sucre, Colombia. Revista Colombiana de Ciencia Animal 1 (1): 60-64.

Navarro IL, Roman AK, Gómez FH, Pérez A (2011) Variación estacional en escarabajos coprófagos (Coleoptera: Scarabaeidae: Scarabaeinae) de la serranía de Coraza, Sucre (Colombia). Revista Colombiana de Ciencia Animal 3 (1): 102-110.

Neita-Moreno JC (2011) Escarabajos (Coleoptera: Scarabaeoidea) del departamento del Chocó, Colombia. Revista Biodiversidad Neotropical 1 (1): 17-27. https://doi.org/10.18636/bioneotropical. v1i1.25

Neita-Moreno JC, Yepes F (2011a) Description of the larva and pupa of Dyscinetus dubius (Coleoptera: Melolonthidae: Dynastinae: Cyclocephalini). Revista Colombiana de Entomología 37 (1): $152-156$.

Neita-Moreno JC, Yepes F (2011b) Nuevos datos sobre la biología y distribución de la especie Dyscinetus dubius en Colombia, descripción de larva y pupa y clave para la identificación de las 
larvas del tercer estadio de las especies conocidas para el género Dyscinetus. Revista Bioetnia 8 (1): 53-57.

Neita M, César J, Orozco A, Ratcliffe BC (2006) Escarabajos (Scarabaeidae: Pleurosticti) de la selva baja del bosque pluvial tropical “BP-T”, Chocó, Colombia. Acta Zoológica Mexicana 22 (2): 1-32.

Nichols E, Larsen T, Spector S, Davis A, Escobar F, Favila M, Vulinec $\mathrm{K}$ (2007) Global dung beetle response to tropical forest modification and fragmentation: a quantitative literature review and meta-analysis. Biological Conservation 137 (1): 1-19. https://doi. org//10.1016/j.biocon.2007.01.023

Noriega JA (2002) First report of the presence of the genus Digitonthophagus (Coleoptera: Scarabaeidae) in Colombia. Caldasia 24 (1): 213-215.

Noriega JA (2004) Preliminary checklist of the scarab community (Coleoptera: Scarabaeidae) at CIEM, Tinigua National Park, Meta-Colombia. Field Studies of Fauna and Flora, La Macarena, Colombia 14: 37-44.

Noriega JA, Barranco W, Hernández J, Hernández E, Castillo S, Monroy D, García H (2016) Estructura estacional del ensamblaje de escarabajos coprófagos (Coleoptera: Scarabaeinae) en una parcela permanente. Revista de la Academia Colombiana de Ciencias Exactas, Físicas y Naturales 40 (154): 75-83. https://doi. org/10.18257/raccefyn. 255

Noriega JA, Horgan F, Larsen T, Valencia G (2010) Records of an invasive dung beetle species, Digitonthophagus gazella (Fabricius, 1787) (Coleoptera: Scarabaeidae), in Peru. Acta Zoológica Mexicana 26 (2): 451-456

Noriega JA, Moreno J, Otavo S (2011) Quince años del arribo del escarabajo coprófago Digitonthophagus gazella (Fabricius, 1787) (Coleoptera: Scarabaeidae) a Colombia: proceso de invasión y posibles efectos de su establecimiento. Biota Colombiana 12 (2): $35-43$

Noriega JA, Solís C, García H, Murillo-Ramos L, Renjifo JM, Olarte JE (2013) Sinopsis de los escarabajos coprófagos (Coleoptera: Scarabaeinae) del Caribe colombiano. Caldasia 35 (2): 465-477.

Otavo SE, Parrado-Rosselli Á, Noriega JA (2013) Superfamilia Scarabaeoidea (Insecta: Coleoptera) como elemento bioindicador de perturbación antropogénica en un parque nacional amazónico. Revista de Biología Tropical 61 (2): 735-752.

Pablo-Cea JD, Velado-Cano MA, Fuentes R, Cruz M, Noriega JA (2017) First report of Digitonthophagus gazella (Fabricius, 1787) and new records for Euoniticellus intermedius (Reiche, 1849) (Coleoptera: Scarabaeidae Latreille, 1802) in El Salvador. Acta Zoológica Mexicana 33 (3): 527-531.

Pablo-Cea JD, Velado-Cano MA, Solís Á (2016) Primer reporte de cuatro especies de escarabajos coprófagos (Coleoptera: Scarabaeinae) en El Salvador. Acta Zoológica Mexicana 32 (1) 218-221.

Padilla-Gil DN, Halffter G (2007) Biogeography of the areas and Canthonini (Coleoptera: Scarabaeidae) of dry tropical forest in Mesoamerica and Colombia. Acta Zoológica Mexicana 23: 73-108.

Pardo-Locarno LC (2013) Escarabajos (Coleoptera: Melolonthidae) del plan aluvial del Río Cauca, Colombia I. Ensamblaje, fichas bioecológicas, extinciones locales y clave para adultos. Dugesiana 20 (1): 1-15.

Pardo-Locarno LC, Camero E (2014) Escarabajos coprófagos (Coleptera Scarabaeinae) en siete microcuencas del río Dagua, Chocó biogeográfico de Colombia. Boletín de la SEA 54: 207-224.

Pardo-Locarno LC, González JC, Pérez CR, Yepes F, Fernández C (2012) Escarabajos de importancia agrícola (Coleoptera: Melolonthidae) en la Región Caribe colombiana: registros y propuestas de manejo. Boletín del Museo Entomológico Francisco Luis Gallejo 4: 7-23.

Pardo-Locarno LC, Lozano-Zambrano FH, Montoya-Lerma J (2000) Passalidae (Coleoptera: Scarabaeoidea) en fragmentos de bosque seco tropical de la cuenca media del Rio Cauca, Colombia. Folia Entomológica Mexicana 110: 15-22.

Pardo-Locarno LC, Montoya-Lerma J, Bellotti AC, Van Schoonhoven
A (2005). Structure and composition of the white grub complex (Coleoptera: Scarabaeidae) in agroecological systems of northern Cauca, Colombia. Florida Entomologist 88 (4): 355-363. https:// doi.org/10.1653/0015-4040(2005)88[355:SACOTW]2.0.CO;2

Pardo-Locarno LC, Montoya-Lerma J, Schoonhoven A (2003) Abundancia de Chisas Rizofagas (Coleoptera: Melolonthidae) en Agroecosistemas de Caldono y Buenos Aires, Cauca, Colombia. Revista Colombiana de Entomología 29 (2): 177-183.

Pardo-Locarno LC, Montoya J (2007) Ciclo de vida, importancia agrícola y manejo integrado de la chisa rizófaga Phyllophaga menetriesi Blanchard (Coleoptera: Melolonthidae), en Cauca y Quindío, Colombia. Acta Agronómica 56 (4): 195-202.

Pardo-Locarno LC, Morón MA (2006) Redescripción de inmaduros y distribución de la Chisa Phyllophaga menetriesi (Blanchard) en los Andes colombianos (Coleoptera: Melolonthidae). Acta Agronómica 55 (4): 13-20.

Pardo-Locarno LC, Morón MA, Montoya-Lerma J (2006) Descripción de los estados inmaduros de Leucothyreus femoratus Burmeister (Coleoptera: Melolonthidae: Rutelinae: Geniatini) con notas sobre su biología e importancia agrícola en Colombia. Folia Entomológica Mexicana 45 (2): 179-193.

Pardo-Locarno LC, Yepes F, Posada-Flórez FJ (2017) Morfología larval e importancia agronómica de tres especies de anomalini colombianos (Coleoptera: Scarabaeoidea), con una clave para larvas de especies americanas. Boletín del Museo de Entomología de la Universidad del Valle 17 (2): 1-15.

Peck S (2010) The beetles of the Island of St. Vincent, Lesser Antilles (Insecta: Coleoptera): diversity \& distribution. Insecta Mundi 0144: 1-78

Peck S, Cook J, Hardy J (2002) Beetle fauna of the Island of Tobago, Trinidad and Tobago, West Indies. Insecta Mundi 0016: 9-23.

Proppe DS, Sturdy CB, St Clair CC (2013) Anthropogenic noise decreases urban songbird diversity and may contribute to homogenization. Global Change Biology 19 (4): 1075-1084. https://doi. org/10.1111/gcb.12098

Pulido-Herrera LA, Zunino M (2007) Catálogo preliminar de los Onthophagini de América (Coleoptera: Scarabaeinae). Escarabajos, diversidad y conservación biológica Ensayos en homenaje a Gonzalo Halffter 7: 93-129.

Ramírez-Ponce A, Morón MÁ (2009) Relaciones filogenéticas del género Anomala (Coleoptera: Melolonthidae: Rutelinae). Revista Mexicana de Biodiversidad 80: 357-394.

Rangel-Acosta JL, Hernández NJM, Gutierrez-Rapalino BP, Gutierrez-Moreno LC, Borja-Acuña RA (2016) Efecto del tamaño de la ronda hidráulica sobre las comunidades de escarabajos coprófagos (Scarabaeidae: Scarabaeinae) en la cuenca media y baja del rio Cesar, Colombia. Entomotropica 31: 109-130.

Rangel-Acosta JL, Martínez-Hernández NJ (2017) Comparación de los ensamblajes de escarabajos copronecrófagos (Scarabaeidae: Scarabaeinae) entre fragmentos de bosque seco tropical y la matriz adyacente en el departamento del Atlántico-Colombia. Revista Mexicana de Biodiversidad 88 (2): 389-401.

Ratcliffe BC (1976) A revision of the genus Strategus (Coleoptera: Scarabaeidae). Bulletin of the University of Nebraska State Museum 10: 93-204.

Ratcliffe BC (1986) Two new species of Dyscinetus from the West Indies and South America (Coleoptera: Scarabaeidae: Dynastinae). The Coleopterists Bulletin, 40 (1): 75-80.

Ratcliffe BC (2002) A checklist of the Scarabaeoidea (Coleoptera) of Panama. Zootaxa 32 (1): 1-48.

Ratcliffe BC (2003) The Dynastinae scarab beetles of Costa Rica and Panama. Bulletin of the University of Nebraska State Museum 16: 1-506.

Ratcliffe BC (2011) A review of the species of Phileurus Latreille (Coleoptera: Scarabaeidae: dynastinae: Phileurini) with quadridentate protibiae and description of a new species from Panama The Coleopterists Bulletin 65: 125-129. https://oi.org/10.1649/ 072.065 .0203 
Ratcliffe BC, Cave RD (2006) The ynastinae scarab beetles of Honduras, Nicaragua and El Salvador. Bulletin of the University of Nebraska State Museum 21: 1-424.

Ratcliffe BC, Cave RD, Cano EB (2013) The dynastine scarab beetles of Mexico, Guatemala, and Belize (Coleoptera: Scarabaeidae: Dynastinae). Bulletin of the University of Nebraska State Museum 27: 1-666.

Ratcliffe BC, Jameson ML, Figueroa L, Cave RD, Paulsen MJ, Cano EB, Jimenez-Ferbans L, Reyes-Castillo P (2015) Beetles (Coleoptera) of Peru: a survey of the families. Scarabaeoidea. Journal of the Kansas Entomological Society 88 (2): 186-207. https://doi org/10.2317/kent-88-02-186-207.1

Ratcliffe C, Morón MA (2005) Larval descriptions of eight species of Megasoma Kirby (Coleoptera: Scarabaeidae: Dynastinae) with a key for identification and notes on biology. The Coleopterists Bulletin 59 (1): 91-126.

Restrepo-Giraldo H, Morón MA, Vallejo F, Pardo-Locarno LC, López-Ávila A (2003) Catálogo de Coleoptera Melolonthidae (Scarabaeidae Pleurosticti) de Colombia. Folia Entomológica Mexicana 42 (2): 239-263.

Reyes-Castillo P (1970) Coleoptera, Passalidae: morfología y división en grandes grupos; géneros americanos. Folia Entomológica Mexicana 20 (22): 217-232.

Reyes-Castillo P (1973) Passalidae de la Guyana Francesa (Coleoptera, Lamellicornia). Bulletin du Muséum National d'Histoire Naturalle 197: 1541-1587.

Reyes-Castillo P, Amat-García G (2003) Passalidae (Coleoptera) de Colombia. Escarabeidos de Latinoamérica: Estado del conocimiento Monografías Tercer Milenio 3: 35-50.

Ripa RS, Rojas PS (1995) Releases of biological control agents of insects pests on Easter Island (Pacific Ocean). Entomophaga 40 (3-4): 427-440.

Rivera-Cervantes LE, García-R E (1991) New locality records for Onthophagus gazella Fabricius (Coleoptera: Scarabaeidae) in Jalisco, México. The Coleopterists Bulletin 45 (4): 370.

Ruiz MA (2000) Levantamento populacional de besouros coprofagos (Coleoptera Scarabaeidae) no Estado de Amambay, Republica do Paraguay. Dissertaçâo de Mestrado em Entomologia, Escola Superior de Agricultura "Luis de Queiroz", Universidade de Sao Paulo, Piracicaba, Brazil, 80 pp.

Salazar-Niño K, Amat-García G (2015) Una aproximación al conocimiento de los escarabajos pasálidos (Coleoptera: Passalidae) de la Orinoquia colombiana. In: Rangel O (Ed.) Colombia Diversidad Biótica XIV la región de la Orinoquia colombiana. Universidad Nacional de Colombia, Bogotá, 627-634.

Salazar F, Donoso D (2015) Catálogo de insectos con valor forense en el Ecuador. Revista Ecuatoriana de Medicina y Ciencias Biológicas 36 (1): 49-59.

Sanabria-García R, Gasca-Álvarez HJ, Amat-García G (2012) Sinopsis de la Tribu Oryctini (Coleoptera: Scarabaeidae: Dynastinae) de Colombia. Insecta Mundi 0276: 1-64.

Sarmiento-Garcés RA, Amat-García G (2014) Escarabajos del género Dichotomius Hope 1838 (Scarabaeidae: Scarabaeinae) en Colombia. Universidad Nacional de Colombia, Bogotá, 134 pp.

Schhuster J (1978) Biogeographical and ecological limits of New World Passalidae. The Coleopterists Bulletin 32 (1): 21-28.

Schoolmeesters P (2019) Scarabs: World Scarabaeidae Database (version Jan 2019). In: Roskov Y, Ower G, Orrell T, Nicolson D, Bailly N, Kirk PM, Bourgoin T, DeWalt RE, Decock W, van Nieukerken E, Zarucchi J, Penev L (Eds) Species 2000 \& ITIS Catalogue of Life. http://www.catalogueoflife.org/col. Naturalis, Leiden. Accessed on: 2019-3-1.
Scholtz C (1990) Revision of the Trogidae of South America (Coleoptera: Scarabaeoidea). Journal of Natural History 24: 1391-1456. https://doi.org/10.1080/00222939000770841

Smith ABT, Skelley PE (2007) A review of the Aphodiinae (Coleoptera: Scarabaeidae) of southern South America. Zootaxa 1458 (1): 1-80. https://doi.org/10.11646/zootaxa.1458.1.1

Solis A, Kohlmann B (2012) Checklist and distribution atlas of the Scarabaeinae (Coleoptera: Scarabaeidae) of Costa Rica. Zootaxa 3482 (2): 1-32.

Solís A, Kohlmann B (2002) El género Canthon (Coleoptera: Scarabaeidae) en Costa Rica. Giornale Italiano di Entomologia 10 (50): 1-68.

Solís A, Kohlmann B (2004) El género Canthidium (Coleoptera: Scarabaeidae) en Costa Rica. Giornale Italiano di Entomologia 11 (52): 1-73.

Solís A, Kohlmann B (2013) El género Uroxys (Coleoptera: Scarabaeidae) en Costa Rica. Giornale Italiano di Entomologia 13 (58): 289-340.

Solís A, Morón MA (1998) Distribución, diversidad e importancia de las especies de Phyllophaga Harris en Costa Rica (Coleoptera: Melolonthidae). In: Morón MA, Aragón A (Eds) Avances en el estudio de la diversidad, importancia y manejo de los coleópteros edafícolas americanos. Publicación especial de la Benemérita Universidad Autónoma de Puebla y la Sociedad Mexicana de Entomología, A.C. Puebla, México, 19-28.

Soula M (2009) Les coléoptères du Nouveau Monde. Volume 3: Rutelini 3. Révision des Pelidnotina 3 Besoiro: Supplément au Bulletin de liaison de l'Association Entomologique pour la Connaissance de la Faune Tropicale AECFT. Saintry, France, 1: 1-137.

Suárez MA, Amat-García G (2007) Lista de especies de escarabajos fruteros (Melolonthidae: Cetoniinae) de Colombia. Biota Colombiana 8 (1): 69-76.

Taboada-Verona C, Faúndez EI, Sierra-Serrano O (2016) Reporte de un caso teratológico en Pelidnota polita Latreille, 1812 (Coleoptera: Scarabaeidae: Rutelinae) en Colombia. Boletín de la Sociedad Entomológica Aragonesa 59: 303-304.

Útima O, Vallejo LF (2008) Escarabajos Melolonthidae (ScarabaeidaePleurosticti) de la montaña cafetera, departamento de Risaralda, Colombia. Agronómica 16 (2): 31-44.

Vallejo LF, Wolff M (2013) The genus Phyllophaga Harris (Coleoptera: Scarabaeidae: Melolonthinae) in the Colombian Andean Mountains. Zootaxa 3722: 101-142. https://doi.org/10.11646/zoo taxa.3722.2.1

Vásquez HMG, Hernández-Cruz J (2018) Registro de Gymnetis stellata (Latrielle, 1833) en Oaxaca, México. Southwestern Entomologist 43 (2): 547-550.

Vidaurre T, Noriega JA, Ledezma MJ (2008) First report on the distribution of Digitonthophagus gazella (Fabricius, 1787) (Coleoptera: Scarabaeidae) in Bolivia. Acta Zoológica Mexicana 24 (3): 217-220.

Villamarín-Cortez S (2010) Escarabajos Estercoleros (Coleoptera: Scarabaeinae) de El Goaltal, provincia de Carchi, Ecuador: lista anotada de especies y ecología. Avances en Ciencias e Ingenierías 2 (3): 98-103.

Vitousek PM, Mooney HA, Lubchenco J, Melillo JM (1997) Human domination of Earth's ecosystems. Science 277 (5325): 494-499. https://doi.org/10.1126/science.277.5325.494

Vulcano MA, Pereira FS (1964) Catalogue of the Canthonini (Col. Scarab.) inhabiting the Western Hemisphere. Entomologische Arbeiten aus dem Museum G. Frey 15: 570-685.

Vulcano MA, Pereira FS (1967) Sinópse dos Passalidae e Scarabaeidae s. str. da região amazônica (Insecta, Coleoptera). Atas do Simposio sôbre a Biota Amazônica 5: 533-603. 